\title{
Çeçenistan: Siyasi ve Askerî Kısırdöngü
}

\author{
Chechnya: Political and Military Vicious Circle
}

\author{
Mesut UYAR*
}

$\ddot{O} z$

Çeçenler tek başlarına veya diğer Kafkas milletleriyle beraber 1750'den beri Rus işgali ve yönetimine karşı direnmektedir. Bu direniş 1850 'ler ve 1990 'larda tepe noktasına çıkmıştır. Bu makalenin iddiası, bu iki tepe noktasında Çeçenlerin ve Rusların çözüm getirmeyen aynı stratejileri ve yöntemleri uyguladıkları ve geçmişten hiçbir ders almadıklarıdır. Bu kısırdöngü iyi analiz edilirse, gelecekte soruna barış̧̧ı çözüm bulmak mümkün olacaktır.

Anahtar Kelimeler: Çeçenistan, Rusya, Gayri Nizami Harp, Ayrllıkçı Milliyetçilik, Şeyh Şamil.

\section{Abstract}

Chechens have fought against Russian occupation and administration since 1750 by themselves or with other Caucasian nations. This struggle has reached its peak once in 1850s and then again in 1990s. The main thesis of this article is that both Chechens and Russians had applied the same pointless strategy and methods and that they had not learned anything from history. If this vicious circle is examined thoroughly, a peaceful conflict resolution will be available.

Keywords: Chechnya, Russia, Unconventional Warfare, Separatist Nationalism, Sheik Shamil.

\footnotetext{
* Prof.Dr., Antalya Bilim Üniversitesi, İktisadi, İdari ve Sosyal Bilimler Fakültesi, e-posta: mesut.uyar@antalya.edu.tr.
}

Geliş Tarihi/Received: 28.08.2018

Kabul Tarihi/Accepted: 26.10.2018 


\section{Giriş}

Modern tarihin kurucusu olarak kabul edilen antik Yunan asker ve siyasetçi Tükidides'in çı̆̆ır açan eseri "Pelopones Savaş1 Tarihi”ni yazarken amacı, gelecek nesillere insan hayatını düzenleyen evrensel yasalarla ilgili bilgileri aktarmaktı. Tükidides'e göre tarih döngüsel bir yapıdaydı. Benzer koşullar altında benzer olayların gerçekleşme olasılığı yüksekti. Tükidides, tabii ki, olayların tamamen benzer cereyan edeceğini iddia etmemektedir. Onun iddiası başta savaş olmak üzere her sosyal olgunun ortaya çıkmasında, cereyanında ve bitişinde rol oynayan temel esaslar tespit edilecek olursa, gelecekteki olası savaş ve olaylara daha hazırlıklı olmak ve daha az hata yapmak mümkün olacaktı. Böylelikle gereksiz şiddet, acılar ve kayıpların önlenebileceği düşüncesindeydi. Tükidides, bu teorisini Atina-Sparta arasındaki Pelopones Savaşı'nda kanıtlamaya çalışmıştı. ${ }^{1}$

Tükidides günümüzde yaşasaydı, Çeçenistan sorunu örneğinde teorisini çok daha rahatlıkla kanıtlayabilirdi. Çeçenistan sorununun 19'uncu yüzyıl başından bu yana gelişimi, hem Rusların, hem de Kuzey Kafkasyalıların ısrarla çözüm sağlamayan aynı politika, strateji, taktik ve tekniklere defalarca başvurduğunu göstermektedir. Bu kısır politika ve uygulamalar, sorunu iyice içinden çıkılamaz hale getirmektedir. $\mathrm{Bu}$ çalışmamızda, Çeçenistan sorununun iki doruk noktası olan 1832-1859 Şeyh Şamil isyanı ve 1991'den 2009'a kadar devam eden bağımsızlık mücadelesi (1'inci ve 2'nci Çeçen Savaşı) mukayeseli olarak incelenmiştir. Amacımız, Şeyh Şamil isyanının verileri 1şığında benzerlik ve farklılıkları ortaya koymak ve hâlihazırdaki mücadelenin geleceğine ve çözümüne yönelik ışık tutmaktır.

\section{Rusların Kuzey Kafkasya'yı İşgali}

Kafkaslar bölgesi, özgün bir coğrafya ve etnik yapıya sahiptir. Bölge, yüzyıllar boyunca Asya ile Avrupa arasındaki önemli ticari, göç

${ }^{1}$ Tükid. I.4-23; Virginia Hunter, Past and Process in Herodotus and Thucydides, Princeton University Press, Princeton, 1982, ss. 102-103, 240-241; T.J. Luce, The Greek Historians, Routledge, 1997, London, ss. 75-76, 87. 
ve tabii ki askerî istila yolu oldu. Yoğun insan akışı ve bölgenin iki önemli medeniyet (Hristiyanlık ve İslamiyet) arasında yer alması, farklı etnik ve dinî yapıdaki insanların bir araya gelmesini sağladı. Arazi yapısının sarp, kırık ve ulaşımın belli yol ve geçitlere bağlı kalması, farklı grupların kimliklerini korumalarını kolaylaştırdığı gibi, aynı kökten gruplar içinde bile farklılaşmaya yol açtı. Yaklaşı 1500 $\mathrm{km}$. uzunluğundaki bu dağ silsilesi, günümüzde elliden fazla etnik-dini grubu barındırmaktadır. ${ }^{2}$

Kafkasya'nın bu özgün coğrafi yapısı, sıcak denizlere ve güneye inme stratejisini güden Rusya'nın hedefi haline gelmesine yol açtı. Ruslar Kafkasya'nın işgaline 27 Temmuz 1722'de I. Petro'nun kendi adını taşıyan Petrovsk (Mahaçkale) üssünü tesis etmesiyle başladı. Dağıstan'ın Hazar sahilinde konuşlu olan bu üs sayesinde, Ruslar iç kesimlere düzenli askerî seferler gerçekleştirebildi. Böylelikle Çeçenlerle Ruslar ilk defa karşılaşmış oldu. Ancak Rusların Kuzey Kafkasya'yı istilası, Güney Kafkasya'daki başarılarının aksine yavaş ve maliyetli bir şekilde gerçekleşti. ${ }^{3}$

İlk örgütlü direniş, din adamı Şeyh Mansur Uşurma'nın önderliğinde 1785 'te başladı. Şeyh Mansur, dinî söylemi ve başlangıçta kazandığı askerî başarılarla kısa sürede büyük bir güç haline geldi. Ancak Osmanlı İmparatorluğu'nun aktif desteğini alamaması ve konvansiyonel savaş yöntemleriyle Rusları yenmeye kalkışması sonucunda başlattığı hareket bir süre sonra dağıldı. Şeyh Mansur, 1787-1791 Osmanl1-Rus Savaşı esnasında tekrar Kuzey Kafkasya’yı ayaklandırmaya çalıssa da, başarılı olamadı ve Ruslar tarafindan

\footnotetext{
2 İslam tarihçi ve coğrafyacılarının bölgeyi "Cebel-i Elsine” (Diller Dağı) diye adlandırması manalıdır. Abdullah Saydam, "Freedom Movements in Northern Caucasia", Eurasian Studies, Cilt. II/1, İlkbahar 1995, s. 90-91; Alexander Grigoriantz, Kafkasya Halklart: Tarihi ve Etnografik Bir Sentez, (çev.) D. Yurdakul, 1. bask1, Sabah Kitapları,1999, İstanbul, ss. 13-17; Moshe Gammer, Muslim Resistance to the Tsar: Shamil and the Conquest of Chechnia and Dagestan, Frank Cass, 1994, London, s. 11-16, 18-22.

${ }^{3}$ Carlotta Gall ve Thomas de Waal, Checnya: A Small Victorious War, Pan Boks, 1997, London, ss. 37-38; Saydam, age, s. 92; Grigoriantz, age, ss. 20-24.
} 

yıl sonra güç kazanacak Müridizm akımının ilk kıvılcımını çaktığı söylenebilir. ${ }^{4}$

Y11: 14

Kafkasya as1l mücadele, 1816'da General Aleksei Yermolov'un Güney Orduları Komutanlığı'na atanmasıyla başladı. Napolyon Savaşları gazisi olan Yermelov, ${ }^{5} 50$ bin kişilik bir orduyla isyancıların asıl odağ1 olan dağlık bölgelerin işgaline başladı. Ruslar, bu tarihe kadar Kafkasya'nın düzlük kesimlerine Kazak kale-yerleşim yerleri (krepost) kurmakla ve dağlık kesimi tahkimli karakol hattı ile kuşatmakla yetinmişti. ${ }^{6}$ Rusların yoğun bir şekilde Kazaklara dayanmasının sebebi, Rus tarzı işgalin bölgede karşılaştı̆̆ temel bir problemdir. Ruslar, bütün istilalarında öncelikle yerel iş birlikçi ve müttefik bulmaya çalışırlardı. Ruslar, Gürcü ve Ermeni desteği sayesinde Güney Kafkasya'yı kolaylıkla işgal etmişken, kuzeyde sadık ve güçlü müttefik bulamadıklarından güvenilir etnik unsurları bölgeye yerleştirmek zorunda kaldılar.

Geçmiş savaş deneyimleri, Yermolov'a "Doğulu”ların ancak güç ve zorbalıkla yola getirilebileceği inancını vermişti. Ona göre, merhamet zayıflıktı. Yermolov'un uyguladığ 1 taktik ve teknikler basitti. Düşmanın en yakın köylerinden başlayarak güç aldığı bütün yerleşim yerleri ayrım yapılmadan imha edildi. Tarla ve bahçeler uzun

\footnotetext{
${ }^{4}$ Zübeyde Güne-Yadcy, "A Chechen National Hero of the Caucasus in the 18th Century: Sheikh Mansur", Central Asian Survey, Cilt XXII/1, Mart 2003, ss. 103-111; Ayrica bkz. İsmail Berkok, Tarihte Kafkasya, İstanbul Matbaası, İstanbul, 1953, ss. 449 öncesi.

${ }^{5}$ Bir başka Napolyon Savaşları gazisi Fransız Mareşali Thomas Robert Bugeaud'un Fransız sömürge savaşlarının kuramcısı olması, ilginç bir bağlantıyı işaret etmektedir. Bugeaud da en az Yermelov kadar sert ve acımasız bir subaydı. Douglas Porch, "Bugeaud, Galliéni, Lyautey: The Development of French Colonial Warfare", (ed.) Peter Paret, John Shy, Makers of Modern Strategy: From Machiavelli to the Nuclear Age, 2. bask1, Princeton Uni. Press, Princeton, 1986, ss. 376-381.

${ }^{6}$ Kuzey Kafkasya'da kentleşme süreci, Rusların Kafkasya'yı işgali ile başladı. 1735'te Kızılyar, 1763 'te Mozdok Kazak kaleleri kuruldu. Bu ve benzeri kaleler, yüz yıllarca Rus ordularının temel üslerini teşkil ettiler. Gall, Waal, age, s. 38; Ufuk Tavkul, "Sovyet Döneminde Kuzey Kafkasya'da Kentleşme”, Tarih ve Toplum, Cilt XVI/94, Ekim 1991, s. 55.
} 
süre kullanılamaz hale getirildi. ${ }^{7}$ İsyancıların rahatça hareket ettiği asırlık ve sık ormanlar, Rus birliklerinin hareketini kolaylaştıracak tarzda yakılıp temizlendi. Yermolov, ele geçirdiği isyancıları ve yöre halkını kullanarak yüzlerce kilometre uzunluğunda ve metrelerce genişlikteki Gürcistan askerî yolunu inşa ettirdi. Yolun inşası esnasında yüzlerce insan ve hayvan soğuktan ve aşırı çalışmadan öldü. Yermolov bunu da planlamıştı. Bir yandan kendi birliklerinin hareket ve ikmal kabiliyetini arttırıyor; diğer yandan da isyanın dayandığ insan gücünü katlederek isyanın kaynağını kurutuyordu. Yermolov, Rusya'dan yeni yerleşimciler getirterek ikinci hat kale-şehirleri inşa ettirdi. Bu yeni şehirler, bir bakıma, yerel halka gözdağı işlevini de üstlenmişti: Grozny (Korkunç), Vnezopnaya (Ani), Burmaya (Fırtına). $\mathrm{Bu}$ tedhiş kampanyası kısa bir süre için ulaşılmaz yüksek zirveler dışında bütün Kafkasya'yı isyancılardan temizlese de, maruz kalınan ağır mezalim ve katliamlar, Rus yönetimine karşı derin bir nefret duygusu ve intikam arzusu doğurdu. İsyanc1lar iyice kemikleşti ve radikalleşti. Yermolov 1827 'de başarısızlıkla suçlanıp geri çağrıldığında, ova kesimleri de dâhil olmak üzere bütün Kafkasya savaş meydanına dönüşmüştü. ${ }^{8}$

\section{2. Şeyh Şamil İsyanı}

Yermolov'un en önemli mirası, Nakşibendi-Halidiye tarikatının radikal bir kolu olan "Müridizm"in doğup taraftar bulmasına yol

\footnotetext{
${ }^{7}$ Yermelov'un karşı gerilla harekâtı, kendisiyle çağdaş Bugeaud'un "razzia" yöntemleriyle neredeyse aynıdır. Razzia, Bugeaud'un Cezayir'de Abdülkadir önderliğindeki isyancıları destekleyen köylülere karşı uyguladığı tedhiş harekâtının adıydı. Tarlalar, bahçeler, köyler sistemli bir şekilde yakılıp tahrip edildi. Fransız askerlerine yönelik her saldırı, sivil halka yönelik yeni baskılara neden olmaktaydı. Sonunda Fransız askerleri halkı katletmekten kadınların ırzına geçmeye varan derecede denetimden çıktı. Uzun razzia uygulaması, kısa vadede isyancıların teslim olmasını sağlasa da, müteakip yüz yıl boyunca devam edecek isyanların anası olmuştur. Porch, age, ss. 380-382.

${ }^{8}$ Gammer, age, ss. 31-38; Lesley Blanch, The Sabres of Paradise, John Murray, 1960, London, ss. 23-26; Paul B. Henze, Kafkaslarda Ateş ve Kulıç: 19ncu Yüzylda Kuzey Kafkasya Dă̆ Köylülerinin Direnişi, (çev.) A. Kösetorunu, ODTÜ Mimarlık Fak. Yay., Ankara, 1985, s. 5.
}

\section{9}

Güvenlik

Stratejileri

Y11: 14

Say1: 28 

Molla'nın (Muhammed ibni İsmail el Gimrivi'nin) başa geçmesiyle ve Rus baskılarıyla savaşçı bir tarikata dönüştü. Müridizm etnik farklar, klanlar (teip) ve kan davalarıyla bölünmüş Dağıstan ve Çeçenistan’ın bir bayrak ve hedef altında toplanmasını sağladı. Şeyh Mansur'dan sonra ilk defa klan dışı ve klan üstü bir siyasi-sosyal yapılanma bölgeye hâkim oldu. Müridizm, hiçbir lüks ve eğlencenin bulunmadığ sade bir hayatı vaaz ediyordu. Tarikat, bölgedeki bütün Ruslar ve destekçileri kovulup öldürülmedikçe inananların günahkâr bir hayat süreceğini iddia ediyordu. Bu günahlardan kurtulmak için tek yol ise cihatt1. ${ }^{9}$

Gazi Molla iyi bir asker ve lider değildi. Bütün gücüyle Ruslarla mücadele edeceğine Çeçen klan ve dinî liderlerini hedef aldı ve onların düşmanlığını kazandı. Tamamen hafif silahlarla teçhiz edilmiş gönüllü ordusuyla gerilla harbini terk edip Rus birlik ve garnizonlarına cepheden saldırmaya kalkıştı. Molla'nın ordusu birbiri ardına ağır yenilgilere uğradı. Bunun sonrasında başlayan Rus karşı taarruzlarına statik köy savunmalarıyla karşılık verdi. 1832 yılında Molla, Gimri köyü savunmasında yakın adamların tamamıyla beraber öldürüldü. ${ }^{10}$

Kafkasya'da en kapsamlı ve örgütlü isyanı, Şeyh Şamil'in Dağıstan İmamı olmasıyla başladı. ${ }^{11}$ Şeyh Şamil, hem karizmatik bir lider, hem de iyi bir gerilla savaşçısıydı. Kendisinden önceki lider ve isyancıların en önemli eksiğinin iyi bir örgütlenmeye gidememeleri ve mesajlarını toplumun her kesimine ulaştıramamaları olduğunu

${ }^{9}$ Müridizm akımının kim tarafından kurulduğu, başlangıç dönemi ve hatta ismi bile tartışmalıdır. Gammer, age, ss. 39-46; Blanch, age, ss. 55-57; Henze, age, ss. 10-11; Milyotin [General Dimitri Milyutin], 1839 Senesinde Şimali Dağıstan'da Yapılan Harp Harekâtu, (çev.) A. Șevket, Askerî Matbaa, İstanbul, 1931, s. 6.

${ }^{10}$ M. Tahir el Karâhi, Kafkasya Mücahidi Şeyh Şamil'in Hatıraları, (haz.) H. Ahmet Özdemir, Kültür Bakanlığı Yayınları, Ankara, 2000, ss. 1-20; Gammer, age, ss. 53-59; Blanch, age, ss. 60-74; Berkok, age, ss. 450-451.

${ }^{11}$ Gazi Molla'dan sonra kısa bir süre imamlığı Hamzat yürüttü. Şeyh Şamil, Hamzat'ın çıkarları sarsılan yerel ağaların düzenlediği bir suikast sonucu öldürülmesinden sonra imam oldu. Karâhi, age, ss. 29-36; Gammer, age, ss. 60-65; Blanch, age, ss. 112-124; Berkok, age, s. 452. 
görmüştü. Şamil, seleflerinden farklı olarak uzun vadeli planlar çerçevesinde programlı bir şekilde isyanı yönlendirdi ve savaşın temel aşamalarını kurguladı. Bu aşamalar şu şekilde sıralanabilir: İlk aşamada, Şeyh Şamil, isyanı koşulsuz ve sonuna kadar destekleyen etnik unsurların bulunduğu bölgelerde asıl üs bölgelerinin teşkil edilmesi ve korunmasına yönelik bir çaba harcadı. Ruslar isyanın tamamen bastırıldığını düşünürken, Şeyh Şamil sessizce bu üs bölgelerini tesis etti. İkinci aşamada, isyanın başarısının önündeki en önemli engelle uğraştı ve çok sayıdaki farklı etnik grup, klan ve çıkar gruplarını aynı bayrak altında toplamaya çalıştı. Ona göre, çözüm isyanın dinî özelliğini daha da arttırmakta yatıyordu. İsyanı gitgide artan boyutta dinî savaş yani cihada dönüştürdü. Müridizm, tam anlamıla savaşçı ve radikal İslamcı bir öğreti halini aldı. Üçüncü aşamada, Şeyh Şamil, Ruslarla iş birliği yapan etnik unsur ve klanlarla uğraştı. Özellikle bir kısım bey ve ağalar Rusların sağladığı iktisadi ve siyasi çıkarlara tamah etmekteydi. Şamil öncelikle bunları kendi safına kazanmaya çalıştı. Direnenleri zor yoluyla hizaya getirdi. Bu şüpheli unsurları asıl savaş dışında lojistik, istihbarat ve keşif faaliyetlerinde kullandı. Böylelikle muharip unsurlar üzerindeki yükü hafifletti. Şeyh Şamil, ancak bu aşamalardaki başarılardan sonra asıl düşmanla savaşa yöneldi. Dördüncü aşamada, Şeyh Şamil artık Rus birlik, tesis ve yerleşim yerlerine yoğun gerilla saldırılarını başlattı. Her fırsat değerlendirilerek düşman üzerindeki baskı gitgide yoğunlaştırıldı. Amaç can ve mal kaybını mümkün olduğunca yükselterek Rus liderlerini ve kamuoyunu çaresiz bırakıp bölgeden çekilme kararı almaya zorlamaktı. Beşinci aşama, aslında bir önceki aşama ile yakından ilgiliydi. Şamil, yoğun gerilla saldırılarının Rus birliklerini kendi üs bölgelerine taarruza iteceğinin farkındaydı. Oynak savunma ve hareketli savaş taktik ve teknikleri uygulanarak Rus birlikleri iç kesimlere yıpratılarak çekilecek ve asıl müstahkem mevkiiler önünde imha edilecekti. Altıncı aşamada, Rus ordusuna indirilen ağır darbeler ve kazanılan zaferler sayesinde Güney Kafkasyalı Müslüman halkları isyana teşvik edilip bu halklarla güçler birleştirerek bütün Kafkasya savaş alanına dönüştürülecekti. Yedinci aşama ise, komşu güçler (Osmanlı ve İran İmparatorlukları) ile Rusya'nın büyük rakiplerinin (İngiltere ve Fransa) aktif yardımlarını 
282

Güvenlik Stratejileri

Y11: 14

Sayı: 28

sağlayarak bağımsız bir devlet kurmaktı. ${ }^{12}$

$\mathrm{Bu}$ aşamalı strateji sayesinde Şeyh Şamil kısa sürede önemli başarılar kazand1. Ancak Şamil'in bütün çabasına rağmen dördüncü aşamadan öteye geçilemedi. İsyan Çeçenistan ve Dağıstan'ın dağlik kesimi dışındaki bölgelere bir türlü yayılamadı. Güney Kafkasyalılarla irtibat tesis edilemedi ve diş destek sağlanamadi. General Grabbe'nin komutasında 1839 yılında başlatılan büyük sefer, her iki tarafın açmazını gösteren önemli bir örnektir. 21 Mayıs-29 Ağustos 1839 tarihleri arasında yaklaşık 25 bin askerin katıldığı harekât boyunca, Rus birlikleri, Şeyh Şamil'in üs bölgelerini ele geçirmek için 7000 askerden fazla zayiat verdi. Buna karşın, inatçı Arguvan ve Akhulgoh savunmaları Şeyh Şamil'in çok değerli mücahitlerini kaybetmesine neden oldu. Oysa daha esnek bir savunma pekâlâ aynı etkiyi doğurabilirdi; çünkü Ruslar bu kadar maliyetle ele geçirilen araziyi ellerinde tutabilecek olanaklara sahip olmadığı için, bölgeyi kısa süre içinde her hâlükârda terk edecekti. ${ }^{13}$

Kuzey Kafkasya'daki savaş, 1845 yılında Kont Mikhail Voronzov'un komutan ve genel vali olarak atanmasıyla temelden değişti. Voronzov tam anlamıyla bir enkaz devralmıştı. Kafkasya, Rus ordusu için öldürücü bir bataklığa dönüşmüştü. Bir Rus askerinin hayatta kalma süresi ortalama üç yıldı. Binlerce asker bakımsızlık, ağır yaşam koşulları, kötü kıyafet-teçhizat ve asıl olarak kötü emir-komuta yüzünden ölüyordu. İnsan gücü o kadar ucuzdu ki, çoğu zaman ağır yaralı ve hasta askerler atlara yapıldığ gibi vuruluyordu. Kafkasya sürgün bölgesi olarak kullanılıyordu. En vasıfsız, disiplinsiz ve etnik açıdan güvenilmeyen birlikler buraya gönderiliyordu. Bu birliklerin komuta makamındaki subaylar da benzeri özellikteydi. Çoğu subay siyasi fikirleri veya disiplinsizlikleri yüzünden buraya sürülmüştü. Aralarında savaş vasıtasıyla makam-rütbe veya iktisadi kazanç sağlamak

${ }^{12}$ Gammer, age, ss. 80-81, 97-98, 107, 117-118, 146-147, 165; Karâhi, age, ss. 111116; Blanch, age, ss. 127-128; Berkok, age, ss. 452-454; Milyotin, age, ss. 10-12.

${ }^{13} 1839$ harekâtının ayrıntılı ancak Rus yanlısı aktarımı için bkz. Milyotin, age; Karâhi, age, ss. 64-80; Gammer, age, ss. 96-109; Berkok, age, ss. 456-465. 
isteyen firsatçılar hiç de azınlıkta değildi. ${ }^{14}$

İsyanı kişisel bir sorun olarak algılayan Çar I. Nikola savaşın her safhasını saraydan idare ediyordu. Ast birlik komutanları, kendilerini göstermek ve çıkar temin etmek için komutanlarını atlayarak doğrudan Çar ile irtibat kuruyorlardı. Sahte zayiat raporları ile Çar ve üst komutanlık kandırılmaktayd. ${ }^{15}$ Haberleşmenin zor ve zaman aldığı o günün şartlarında gerilla savaşı gibi anlık kararlara, inisiyatife ve alt kademe liderliğine dayanan bir mücadeleyi bu tarzda idare etmeye kalkmanın sonuçlarını tahmin etmek zor değildir. Voronzov ilk önce emir-komuta sorununa çözüm buldu. Ancak Voronzov'un asıl reformlara başlaması için talihsiz Dargo Seferi sonucu aşağılatıcı bir yenilgiye uğraması gerekti. Gerekli hazırlık, keşif ve istihbarat yapılmadan plansız ve programsız çııılan sefer sonucu 10.000 kişilik ordunun yaklaşık yarısı kaybedildi. ${ }^{16}$

Bu soğuk duş sonrası, Voronzov köklü reformlar başlattı. Öncelikle subay kadrosunu tamamen değiştirdi. Bölgeye harp okulu mezunu ve iyi eğitim görmüş yüzlerce genç subay atandı. Hemen akabinde, Voronzov,

\footnotetext{
${ }^{14}$ Gammer, age, ss. 23-26; Blanch, age, ss. 134-186. Makam-rütbe, şöhret ve iktisadi kazanç sağlamak için Kafkasya harekâtından istifade edenlere en iyi örnek, İsviçre kökenli bir nevi paralı asker olan Tümgeneral Karl Faesy'dir. Faesy'nin şahsi çıkarları için hiçbir yalan, sahtekârlık ve tahrifattan kaçınmaması, yüzlerce asker ve sivilin hayatına mal oldu; barış firsatlarının kaçırılmasına ve savaşın uzamasına neden oldu. Bkz. Moshe Gammer, "A Switzer in the Caucasus: Faesy's Campaigns in Chechnia and Daghestan", Middle Eastern Studies, Cilt XXX/3, Temmuz 1994, ss. 668-682.

${ }^{15} \mathrm{O}$ dönemde Rus ordusunun görev yapmış başarılı bir kurmay subay olan Milyotin'in 1839 harekâtı ile ilgili verdiği zayiat rakamları ile gerçek rakamlar arasındaki farklar yanıltmanın boyutlarına bir örnektir. Milyotin, Arguvan harekâtı esnasında Rus birliklerin 146 ölü (beşi subay) ve 500 yaralı (30’u subay) askerine karşın, Çeçen zayiatını ölü veya yaralı toplam 2000 olarak vermektedir. Benzer şekilde, Ahulgoh kuşatmasında 500 ölü (23'ü subay) ve 2416 yaralı (94'ü subay) karşın, sadece Çeçen ölü sayısının bile 1000 den fazla olduğunu iddia etmektedir. Milyotin, age, ss. 38-69, 71. Oysa Arguvan'da Rus zayiatı (ölü veya yaralı) 59 subay, 1458 er Çeçen zayiatı 600'dür. Ahulgoh'ta ise Rus zayiatı, 215 subay, 5000 er, Çeçen zayiatı (ölü-yaralı) ise 3000 civarındadır. Berkok, age, ss. 460-463.

${ }^{16}$ Karâhi, age, ss. 139-144; Gammer, Muslim Resistance..., age, ss. 153-161; Blanch, age, ss. 230-247; Berkok, age, ss. 477-478.
} 
isyancılara karşı klasik kuruluşta büyük birlikler kullanıma uygulamasını kaldırdı. Müritlere benzer taktik ve teknikleri uygulayan hafif teçhizatlı, hareket kabiliyeti yüksek, arazi şartlarına uyum sağlamış küçük karş1gerilla birliklerine ağırlık verdi. Bu birlikler asıl olarak Kazaklardan teşkil edilmekle beraber, Kabartaylar gibi sadık yerel unsurlardan da istifade edildi. Bütün bölge Kazak karakollarıyla sarıldı. Kazaklar, bölgenin savunulmasını ve gerilladan temizlenmesini sağladıkları gibi, tarım ve hayvancılıkla uğraşarak kendi ikmallerini de tedarik ediyordu. Karakollar büyük çaplı Mürit saldırılarında birbirine yardım ederken; gerektiğinde merkezî ihtiyat birlikleri de devreye giriyordu. ${ }^{17}$

1856 y1lında Voronzov'un yerine atanan Prens Alexander Bariatinsky, reformların sivil boyutunu başlattı. Bariatinsky, uzun yıllar Kafkasya'da görev yaptığından sorunun daha fazla isyanc1 öldürmekle çözülemeyeceğinin bilincindeydi. Yapılması gereken şey, vurulan askerî darbelerin yanı sıra, isyancılara yönelik halk desteğini zayıflatmak ve halkı kazanmaktı. Eğer bu başarılırsa, aşılmaz arazi kesimlerini bile emniyet altına almak mümkün olacaktı. ${ }^{18}$

İlk olarak, Yermolov mirası olan köy baskınları ve katliam uygulaması kaldırıldı. Tam tersine yıkılmış köylerin imarı, tohum ve damızlık temini, altyapı çalışmaları ile köylülerin iktisadi ve sosyal hayat düzeyi yükseltilmeye çalışıldı. Yerel idareler çoğunluğun sevdiği, saygı duyduğu kişilerden teşkil edildi. Dinî ve yerel geleneklere (adat) dayalı muhafazakâr toplum yapısına müdahale edilememeye gayret gösterildi. Yerel inanış ve yaşayış, Müridizme karşı kullanılmaya çalışıldı. İkinci olarak, yerel iş birlikçiler kazanılmaya çalışıldı. Bu amaçla bey ve klan reislerine büyük siyasi ve iktisadi çıkarlar sağlandı. Böylelikle isyancıların harekât alanı daraltıldı ve kendi içinde kamplara

17 Gammer, age, ss. 175-182, 193, 210-211; Blanch, age, ss. 104-111, 200-201; Voronzov'un reformları, Lord Kitchener'ın Güney Afrika'da Boer isyanını bastırmak amacıyla uyguladığı askeri taktiklere önemli ölçüde benzemektedir. Rayne Kruger, Good-bye Dolly Gray: The Story of the Boer War, 2. bask1, Pan Books, London, 1977, ss. 428- 430, 440, 441, 458-460, 464-465, 469-470.

${ }^{18}$ Blanch, age, s. 300 . 
bölünmesine ve kardeş kavgalarına neden olundu. Ayrıca bu iş birlikçiler, askerî harekâtın başarısı için çok ihtiyaç duyulan keşif ve istihbarat görevlerini de önemli ölçüde üstlendiler. ${ }^{19}$

Rus ordusu tarafında bu köklü reformlar yaşanırken, Şeyh Şamil'in ordusu büyük çözülmeler ve kayıplar sonucu muharebe yeteneğini yitirmeye başladı. Bunun başlıca nedenlerini kısaca şöyle sıralayabiliriz: İlk olarak, uzun mücadele halkı iktisadi ve sosyal açıdan çok yıprattı. İddia edildiği gibi zaferin yakın olması bir yana uzun vadede bile gerçekleşmesinin şüpheli olması, sıkıntılara katlanma azmini kırd. İkinci olarak, uzun zamandan beri beklenen dış desteğin gelmemesi umutları iyice azalttı. Kırım Savaşı sırasında bile isyancılar dış yardım alamadı. Üçüncü olarak, Güney Kafkasya'daki isyan hareketleriyle bir türlü irtibat ve koordine tesis edilemedi. İsyan dışa açılamadı. Dördüncü olarak, din unsuru, geçici bir süre dışında, etnik ve çıkar ayrılıklarının parçaladığı Kafkas halklarının birliğini sağlayamadı. Tam tersine, din öğesinin gitgide ağırlık kazanması ve fanatikleşme, normalde sinırl düzeyde dindar olan kesimlerin harekete desteğini azalttı. Sert şeriat uygulaması, isyana sempati duyan komşu halkları soğuttu. ${ }^{20}$ Son olarak, Şamil uzun ve yıpratıcı mücadele sonucu liderlik yeteneklerini kaybetmeye akılcılıktan uzaklaşmaya başladı. Aksi ve güvensiz bir kişi haline geldi. Yakın müttefiklerini ve naiplerini bile kırmakta, ufak hatalarından dolayı ağır şekilde cezalandırmaktaydı. Üstelik başarılı naipleri kendi liderliği için tehdit gördüğünden makamlarından almaktaydı. Şeyh Şamil zaman içinde gerçek dünyadan iyice koptu. Vaktinin çoğunu dua ederek, namaz kılarak geçirmekteydi. Kısacası mücadelenin bu aşamaya gelmesini sağlayan Şamil, artık liderliği sürdürebilecek durumda değildi. Şeyh Şamil'in yerine geçebilecek kifayetli bir lider adayının yokluğu ise liderlik krizini kronikleştirdi. ${ }^{21}$

\footnotetext{
${ }^{19}$ Gammer, age, ss. 277-291; Blanch, age, ss. 300-301, 394-396.

${ }^{20}$ Berkok, age, ss. 481-483, 492-510; Blanch, age, s. 390; Saydam, age, ss. 99-104; Grigoriantz, age, ss.174-176.

${ }^{21}$ İsyanın önemli komutan ve kahramanlarından Hacı Murat'ın uygulanan yanlış politikalar sonucu taraf değiştirmesi ve öldürülmesi için bkz. Berkok, age, ss. 486-487; Blanch, age, ss.
}

285

Güvenlik Stratejileri

Y11: 14

Say1: 28 
Güvenlik Stratejileri

Y11: 14

Say1: 28

Bariatinsky beklenen son darbeyi 1859 yılı başında vurdu. Gelen son takviyelerle beraber Rus ordusu, Şamil'in asıl dayanak noktası olan Deedo bölgesine yüklendi. Daha önce Rusların adım bile atmayı başaramadığı köyler birer birer düştü. 24 Ağustos'ta Müritlerin son kalesi Gunip ele geçirildi. Şeyh Şamil ailesiyle beraber esir edildi. ${ }^{22}$

Münferit Mürit birlikleri uzunca bir süre daha mücadeleyi sürdürmeyi başardı. Ancak lidersiz, amaçsız ve güçsüz kalan bu gruplar, Ruslar için basit asayiş sorunundan öte anlam taşımıyordu. Elde edilen kesin zafer sonras1, Rus liderler, Bariatinsky'nin yöntemlerini terk edip katliamlara ve köy yakmalarına yeniden başladı. İsyanın bastırılmasında önemli katkıları olan iş birlikçiler de imtiyazlarını kaybedip aynı kaderi paylaştılar. Çoğunluğu Güneyli olmak üzere binlerce Kafkasyalı umutsuzluğa kapılarak Osmanlı İmparatorluğu'na göç etmek zorunda kaldı. 1864 yılına gelindiğinde, gerilla mücadelesi 1877-78 Osmanl1Rus Savaşı'nda (93 Harbi'nde) tekrar canlanmak üzere fiilen bitti. 93 Harbi hem Osmanlı İmparatorluğu, hem de Çeçenistan ve Dağistan isyanı için hezimetle sonuçlandı. 1917 Rus devrimine kadar bölgede büyük çaplı bir isyan çıkmadı. Ancak toplumsal huzursuzluk, sosyal haydutluk hadiseleri, Rusların sindirme ve tedhiş harekâtı devam etti. ${ }^{23}$ 1917 Rus Devrimi sonrasında Kuzey Kafkas Halkları Kongresi toplanarak bölgenin bağımsızlığını ilan etti. Ekim 1918'de Osmanlı ordusunun bölgenin bir kısmını işgali bağımsızlık mücadelesini hızlandırsa da, bu mücadele saman alevi gibi kısa ömürlü oldu. Osmanlı Ordusunun geri çekilmesi ve Beyaz Rusların yenilgisi sonrasında Sovyet Kızıl Ordusu bölgeyi kolayca işgal etti. Mayıs 1921'de son isyancılar da yok edildi. ${ }^{24}$

220-221, 267-268; Gammer, age, ss. 169-170, 215-217, 236-247; Karâhi, age, ss. 159-161.

${ }^{22}$ Blanch, age, s. 404-410; Henze, age, ss. 26-27; Berkok, age, ss. 512-514.

${ }^{23} 1860$ y1lındaki göç, 19'ncu yüzyılın en büyük göçü olarak tarihe geçmiştir. Blanch, age, s.463; Grigoriantz, age, ss. 26, 96-97; Henze, age, s. 28; Berkok, age, ss. 523-530; Saydam, age, ss. 105-107.

${ }^{24}$ Nuri (Killigil) Paşa komutasındaki Kafkas İslam Ordusu'nun Kuzey Kafkasya harekâtı (22 Eylül 1918-27 Kasım 1918) hakkında bkz. Nasır Yüceer, Birinci Dünya Savașı'nda 


\section{Kuzey Kafkasya Bağımsızlık Mücadelesinde Çeçenlerin Rolü}

Rusların bölgeye girmeye başlaması ile beraber, Çeçenler, isyan ve direniş hareketlerinde devamlı olarak yer almış; Şeyh Mansur başta olmak üzere çoğu zaman lider kadroları ve elit birlikleri teşkil etmiştir. Örneğin kendisi Çeçen olmasa da Şeyh Şamil'in yakın çevresi ve seçkin birliklerinin tamamına yakını Çeçen'di. Diğer etnik unsurlardan farklı olarak, Çeçenler, isyanların bastırılma safhasında bile karşı tarafa geçmeyi veya pasif kalmayı seçmeyip sonuna kadar çarpışmışlardır. Çeçenler her firsatta komşu halklarla beraber veya yalnız başlarına ayaklanmışlardır. ${ }^{25}$

$\mathrm{Bu}$ savaşçı ve isyancı gelenek, Çeçenlere çok pahalıya mal olmuştur. Her isyan sonrasında köyleri ve tarlaları yakılmış; ileri gelenleri katledilmiş; başka bölgelere zorunlu iskâna tabii tutulmuşlardır. Şeyh Şamil isyanı sonrasında yaşanan ağır Rus baskısı sonucu, Çeçenlerin bir bölümü, Osmanlı İmparatorluğuna göç etmek zorunda kalmıştır. Çeçenler, 1930 ve 1945 yıllarında ise, Stalin tarafından Kazakistan'da ve Sibirya'da zorunlu iskâna tabi tutulmuş; binlerce Çeçen açlık ve kötü hayat şartları nedeniyle ölmüştür. ${ }^{26}$

Ruslar, bunlarla da yetinmeyip, Çeçenistan'a Rus unsurları ve Ruslara sadık diğer etnik unsurları iskân ederek bir dayanak tesis etmeye

Osmanlı Ordusu'nun Azerbaycan ve Dağıstan Harekâtt, Gnkur. Basımevi, Ankara, 1996, ss.139-162; Saydam, age, ss. 107-117; Mustafa Butbay, Kafkasya Hattraları, çev. A.C. Canbulat, TTK Basımevi, Ankara, 1996, s. 21-95; Bülent Gökay, "Chechnia: A Long History of Conflict, Ressistance and Oppression”, Alternatives, Cilt III/2-3, Yaz-Sonbahar 2004, ss. 6-11.

${ }^{25}$ Karâhi, age, ss. 87-89; Gökay, age, ss. 1-6.

${ }^{26}$ Çeçenler ve kökenleri hakkında bkz. Grigoriantz, age, ss. 168-174; 3 Şubat 1944 tarihinde 425.000 Çeçen ve İnguş trenlere bindirilerek Orta Asya'ya sürgün edildi. Bunlara Stalin'in ölümü sonrasında (1954) geri dönme hakkı tanındı. Göç ettirilen nüfusun ancak \% 58'i geri dönmeyi başard. Niyazi Güney, "Kuzey Kafkasya ve Çeçenistan”, Yeni Türkiye, Cilt I/3, Mart-Nisan 1995, ss. 300-321; Roger Kangas, "Remembering the 1944 Chechen Deportation", http://www,amina.com article/politics. shtml, (Erişim Tarihi: 9 Mart 2000); Mehmet Alpargu, "İkinci Dünya Savaşı'nda Sovyetler'in Kafkasya'daki Tehcir (Sürgün) Uygulamaları", Altıncı Askeri Tarih Semineri Bildirileri, Cilt I, Gnkur Basımevi, Ankara, 1998, ss. 269-278; Gall, Waal, age, ss. 56-68. 

çalışmışlardır. Zaman zaman yumuşamalar olsa da (Bariatinsky ve Kruşçev dönemleri), devamlılık gösteren ve ayrım gözetmeden

Stratejileri

Y11: 14

Sayı: 28 uygulanan sindirme ve tedhiş politikası, Çeçenleri dize getiremediği gibi, aksine Rus düşmanlığının katılaşmasına, millî ve dinî dayanışmanın artmasına neden oldu. 1921'den günümüze kadar devam eden süreçteki durgunluk, Çeçenlerin isyan için uygun ortam bulamamalarından kaynaklıdır. ${ }^{27}$ Ancak zaman içinde Rusçadan başka dil bilmeyen, gelenek ve göreneklere uzak nesillerin de yetiştiği ihmal edilmemelidir. Sovyet yönetimi büyük ölçüde kötü olarak görülse de ciddi bir asimilasyon yaşandığı açıktır.

\section{Birinci Çeçen Savaşı ve Dudayev Dönemi (1990-1996)}

1980'li yılların sonuna doğru Sovyetler Birliği'nde etnik çatışmalar boy göstermeye başladığında yönetim, olası isyanın önüne geçmek için Kuzey Kafkaslarda birbiri ardına siyasi reformlar yaptı. Örneğin Çeçen-İnguş Özerk Cumhuriyetine ilk defa yerli halktan idareciler atandı. Ancak çok geç kalınmıştı. Genelde Kafkaslar, özelde Çeçen-İnguş Özerk Cumhuriyeti kaynamaya başlamıştı. Dönemin Sovyetler Birliği Lideri Mihail Gorbaçov yönetimine yönelik darbe girişimi sonucu patlak veren kaostan istifadeyle, 15 Ekim 1991'de Sovyet eski generali Cahar Dudayev (veya Cevher Dudayi) önderliğindeki bağımsızlık yanlıları yönetimi ele geçirdi. 27 Kasım'da Dudayev başkan seçildi. $^{28}$

${ }^{27}$ John Colarusso, "Chechnya: The War Without Winners", Current History, Cilt XCIV/594, Ekim 1995, s. 330; Havva Kök, "Chechen Crisis and Russia's Future", Foreign Policy, Cilt XIX/1-2, 1995, ss. 37-39; Gall, Waal, age, ss. 70-75.

${ }^{28}$ Dönemin Çeçenistan-İnguş Özerk Cumhuriyeti Başkanı Doku Zavgaev'in 19 Ağustos 1991'de gerçekleştirilen darbeyi desteklemesi ve sonrasında Yeltsin tarafindan görevden alınması, Dudayev'in önünü açtı. Boris Moskalev, "The Anatomy of the Chechen Conflict”, Mediterranean Quarterly, Cilt VII/1, Kış 1996, s. 101; Dudayev'in başkan seçilmesinde başarılı bir general olması yanı sıra güçsüz ve küçük bir klana mensup olmasının da büyük bir önemi vardır. Böylelikle güçlü klanlar arasında çatışmaları önleyecek ve dengeyi sağlayacak tarafsızlığa sahip biri olarak algılandı. Colarusso, age., s. 330-331; Gall, Waal, age., s. 83-99; Anatol Lieven, Chechnya: Tombstone of Russian Power, Yale University Press, New Haven, 1998, ss. 58-63. 
1 Kasım'da Çeçen-İnguş Özerk Cumhuriyeti, Sovyetler Birliği'nden bağımsızlı̆ıını ilan etti. 30 Kasım'da İnguşlar yeni kurulan Rusya Federasyonu'na bağlı olduklarını bildirerek Çeçenlerden ayrıldı. Kafkaslarda etnik farklılık ve çatışma o kadar büyüktü ki, yakın akraba durumundaki İnguşlar, Çeçen ağılıklı bir devletin parçası olmaktansa Rus yönetimini tercih etmişlerdi. ${ }^{29}$

Rusya Federasyonu Başkanı Boris Yeltsin, büyük bir paniğe kapılıp bağımsızlık kararını tanımayarak Çeçenistan'ın tamamını kapsayan sıkıyönetim ilan etti. İçişleri Bakanlığına bağlı özel birlikler başkent Grozny'e gönderildi. Dudayev, bunu Yeltsin'in siyasi muhalifleri vasıtasıyla önceden haber alıp Rus birliklerini havaalanında kıstırdı. Ruslar silahlarını Çeçenlere teslim ederek canlarını kurtarabildiler. Bu geri çekilme, Rusya için ve özellikle de Yeltsin için utanç verici bir darbe oldu. Çeçenistan ekonomik abluka altına alındı. Siyasi krizin ve ekonomik ablukanın beklenmedik sonucu, bir asırdan uzun süredir farklı Rus ve Sovyet hükümetlerinin planlı bir şekilde yerleştirdiği Rusların bölgeden kaçışına yol açması olmuştur. Çeçenistan'da geride sadece gidecek yeri olmayan fakirler ve emekliler kaldı. Yeltsin böylece bilinçsizce etnik temizlik yapıp Çeçen unsurunu kuvvetlendirmiş oldu. ${ }^{30}$

Rusların kitleler halinde kaçışını başlangıçta sevinilecek bir gelişme olarak gören Çeçenler, abluka nedeniyle olduğu kadar petrol endüstrisinin yetişmiş Rus mühendis ve işçilerinin terk etmesiyle de ekonomik darboğaz içine düştü. Dudayev 1992 yılı boyunca başta Türkiye olmak üzere Müslüman ülkeleri ve Batılı devletleri dolaşarak destek aradı. Ancak aradığı ekonomik desteği bulamayab Dudayev, organize suç şebekelerine göz yummak zorunda kaldı. ${ }^{31}$

\footnotetext{
29 İnguşlar ve kökenleri hakkında bkz. Grigoriantz, age, ss. 177-186; Şeyh Şamil isyanı sırasında da benzeri bir ayrılık gerçekleşmiş; İnguşlar, Rus tarafina geçerek Çeçenleri yüzüstü bırakmıştı. Lieven, age, ss. 61, 70-71, 100; Colarusso, age., s. 331; Blanch, age., s. 396.

${ }^{30}$ Pavel Felyenhauer, "The Chechen Campaign”, http://www.amina.com/article/politics.shtml, (Erişim Tarihi: 9 Mart 2000); Moskalev, age., ss. 102-105; Lieven, age, ss. 63-65.

${ }^{31}$ Dudayev, Kasım 1992'de Amerika'ya gizlice girerek petrol şirketleriyle görüşsmüş ancak
} 
Çeçenistan'a destek veren suç şebekelerini iki ana grup içinde Stratejileri değerlendirebiliriz. Birinci grup, Orta Doğu kökenli İslamcı terör örgütleridir. İkinci grup ise Rusya ve hatta eski Doğu Bloku ülkelerinde

Y11: 14 etkin olan Çeçen mafyasıdır. Dudayev'in bu örgütlerin faaliyetlerine göz Say1: 28 yummasının ardından, Çeçenistan, bir anda bölgenin en önemli silah kaçakçılı̆̆ 1 , uyuşturucu ticareti ve kara para aklama merkezi oldu. Teröristlerin yetiştirildiği ve saklandığı kamplar birbiri ardına açıldı. Özellikle silah ticareti öyle büyüyüp para kazandırmaya başladı ki, her tür normal ticari faaliyet bir kenara birakıldd $1{ }^{32}$

Suç örgütleri ile iş birliğinin iki önemli menfi etkisi oldu. Birinci olarak, ülke içinde huzur, güven ve iç barış bozuldu. Sırtını mafyalara dayayan klanlar bağımsız birer güç ve derebeyi haline geldi. İkincisi ise, Rusya'nın yoğun propagandası ile Batılı ülkelerde Çeçenistan'a karşı büyük bir antipati ve güvensizlik hasıl oldu. Rusya'nın haksız ve sert yaptırımları meşru görülmeye başlandı. ${ }^{33}$

Ülke içinde klanlar arası mücadelenin gerginleşmesi ve bir türlü etkin, meşru ve adil bir idarenin kurulamaması sonucu, Dudayev 4 Haziran 1993'te parlamentoyu feshetti. Muhalefet ezildi veya başkenti terke mecbur bırakıldı. Çeçenistan'da bu gelişmeler olurken, Ekim 1993'te Yeltsin askerî güç kullanarak Rus Parlamentosunu basıp

istediği teknik ve mali desteği sağlayamamıştır. Colarusso, age., s.332; Lieven, age, ss. 7475; David. J.Kramer, "Time to Act on Chechnya", http://www.amina.com/article/ politics.shtml, (Erişim Tarihi: 9 Mart 2000); Eric Margolis, "Crime without PunishmentRussia in the Caucasus", http://www.amina.com/ article/ politics.shtml, (Erişim Tarihi: 9 Mart 2000).

${ }^{32}$ Turbiville, Çeçen mafyasının Dudayev'in desteği sayesinde dünya çapında etkin bir suç şebekesi haline geldiğini iddia etmektedir. Graham H. Turbiville, "The Chechen EthnoReligious Conflict, Terrorism and Crime", Military Review, Cilt LXXIV/3, Mart 1994. Çeçenistan yönetimi ve suç örgütleri ilişkileri ile bölgenin suç cenneti haline gelmesine yönelik Rus iddiaları için bkz. Vladimir Torin, "The Workings of the Caucasian Mechanism", http: //www.amina.com, (Erişim Tarihi: 9 Mart 2000); Moskalev, age, ss. 105-110.

${ }^{33}$ Turbiville, age, ss. 20-22; Colarusso, age, s. 332; Gall, Waal, age, ss. 124-136; Stephen Blank, "Yeltsin's Folly: The Russian Invasion of Chechnya", Mediterranean Quarterly, Cilt VI/3, Yaz 1995, ss. 93-103. 
muhalefet önderlerini tutuklattı. Yeltsin, bundan böyle, demokratik güçler ve halk yerine "Savaş Partisi" denen İçişleri ve İstihbarat Bakanlıklarına dayanacaktı. Yeltsin'in ikinci hamlesi, Çeçen sorunu hakkında olacaktı. Yeltsin başından itibaren sorunu kişisel bir problem olarak algiliyordu ve bu problemi halk nezdindeki prestijini tekrar kazanmak için uygun bir firsat olarak değerlendirdi. Yeltsin ayrıca üst üste yaşanan darbelerin utancını da temizlemek istiyordu. İkincisi, Azerbaycan ve Kazakistan petrol sahaları dünya pazarına açılmak üzereydi. Çeçenistan, ana boru hatları üzerinde önemli bir kavşak noktası olduğu gibi, stratejik öneme haiz yüksek kalitede petrol rezervine sahipti. Üçüncüsü, Çeçenler Rusya bünyesindeki diğer etnik unsurlara örnek olup ikinci parçalanma sürecini başlatabilirdi. Sonuncusu ise geniş Rus ovasını güneye karşı koruyan tampon dağlık kesim kaybedileceği gibi Güney Kafkas devletleri (Azerbaycan, Gürcistan, Ermenistan) üzerindeki etki ve denetim kaybolacaktı. ${ }^{34}$

Öyleyse Rusya bir an önce harekete geçmeliydi. Önce Usman Avturkhanov ve Ruslan Hasbulatov gibi Dudayev muhalifleri desteklenerek yönetim devrilmeye çalışıldı. Bu sonuçsuz kalınca, İçişleri ve İstihbarat Bakanlıkları kendi kuvvetleri ve bazı kiralık ordu birlikleri ile Grozny'ye 28 Kasım 1994'te taarruz etti. Sonuç tam bir fiyaskoydu. Çeçenler ikinci kez Rusya'yı utanç verici bir yenilgiye uğrattı. ${ }^{35}$ Bunun üzerine Yeltsin uzun pazarlık ve hesaplamalardan sonra Rus düzenli

\footnotetext{
${ }^{34}$ Sebastian Smith, Allah's Mountains: The Battle for Chechnya, Tauris Parke, London, 2006, ss. 123-124, 128-135; Omar Ashour, "Security, Oil and Internal Politics: The Causes of the Russo-Chechen Conflicts", Studies in Conflict\&Terrorism, Cilt XXVII, 2003, ss. 131-133; Kök, age., s. 40-41; Felgenhauer, age; Robert E. Ebel, "The History and Politics of Chechen Oil", http://www.amina.com/ article/politics.shtml, (Erişim Tarihi: 9 Mart 2000); Stephen Blank, "Russia's Real Drive to the South", ORBIS, Cilt XXIX/3, Yaz 1995, ss. 369-380.

${ }^{35}$ Rus bakanlıkları arası güç mücadelesi o kadar büyük boyuta ulaşmıştı ki, İstihbarat Bakanı, Savunma Bakanı'ndan gizli olarak bazı askerî birlikleri para ile kiraladı. Amaç, zaferin prestijini başkalarıyla paylaşmayıp iktidar mücadelesinde güç kazanmaktı. Colarusso, age, s. 333; Gall, Waal, age, 155-161; Lieven, age, ss. 86-92. Aslında gerçek anlamda örgütlü bir Dudayev karşııtı Çeçen muhalefeti bulunmuyordu. Moskalev, age, ss. 113-115.
} 
birliklerini Çeçenistan'a gönderdi. ${ }^{36} 11$ Aralık’ta Rus askerî birlikleri üç koldan taarruza geçti. İnguşetya ve Doğu Dağıstan'dan geçen birlikler

Güvenlik Stratejileri

Y11: 14

Sayı: 28 yerli halkın saldırısına maruz kaldı. Çeçenistan'a girdiklerinde, halkın pasif direnişi ve yol kapamaları karşısında taarruz durdu. 13 Aralık'tan itibaren Grozny bombalanmaya başladı ve şehre nihai taarruz 31 Aralık'ta başlatıldı. Sonuç, Rusya için üçüncü bir fiyasko idi. Rus askerleri ağır kayıplar sonrası çekildi. Bunun üzerine, Rus komuta heyeti içindekiler savaşamayacak hale gelinceye kadar şehri bombalama kararı aldı. Yoğun ve hedef ayrımı yapılmadan icra edilen bir bombardıman sonrasinda 19 Ocak 1995 'te Grozny düştü. ${ }^{37}$

Grozny başta olmak üzere bütün önemli yerleşim yerlerinin Rus birliklerinin eline geçmesi, Çeçenlerin mücadele azmini kırmadı. Tam tersine, aslında yerleşim yerlerinin hafif silahlı gerillalar tarafindan savunulması, kazandıkları olağanüstü başarılara rağmen anlamsızdı. Şehirlerin düşmesiyle Çeçenler ayak bağlarından kurtuldu. Dudayev savaşı kırsal alana taşıdı. Artık Rus birliklerine karşı daha az zayiatla etkin bir şekilde saldırma imkânı kazanılmıştı. Çeçenlerin uyguladığı gerilla savaş1; moralsiz, emir-komuta sistemi bozulmuş, ikmal ve iaşesi problemli Rus ordusunu önemli ölçüde sarstı. "Savaş Partisi"nin nihai darbeyi vurma çabaları, ordunun beceriksizliği sayesinde sonuçsuz kaldı. Gerilla saldırılarının yoğunluğu ve Rusların buna karşı bir türlü çözüm bulamaması, Rus birliklerinin uçaklarını ve ağır topçu silahlarını hiçbir kısıt gözetmeden kullanmalarına yol açtı. Bu yöntem, savunacak

${ }^{36}$ Çeçenistan'ın işgaline karar verilmesi, Kremlin kökenli politikacıların ne kadar çok kendi çıkarlarını düşündüğüne iyi bir örnektir. Rusya'nın ve halkının çıkarları, uluslararası ilişkiler ve her şeyden önce Çeçenistan halkı tamamen göz ardı edildi. Gall, Waal, age, ss. 161-167; Lieven, age, ss. 94-96.

37 Kuşatmanın sonlarına doğru saatte 4000 top mermisi ve uçak bombasının atıldığı kaydedilmiştir. Başlangıçta sayıları 1000 civarında olan Çeçen gerillalar, 40.000 mevcuduna ulaşan ve her tür ağır silaha sahip Rus ordusunu defalarca püskürtmeyi ve ağır zayiat verdirmeyi başard1. Gall, Waal, age, ss. 204-227; Smith, age, ss. 146-166; Colarusso, age, ss. 333-334; George J. Church, "Death Trap", Time, 16 Ocak 1995, ss. 15-20; Timothy L. Thomas, "The Battle of Grozny: Deadly Classroom for Urban Combat", Parameters, Cilt XXIX/2, Yaz 1999, ss. 87-101; Lieven, age, ss. 102-116. 
sabit mevzii olmayan gerillaya hiçbir zarar vermedi. Tam tersine, sadece sivillerin öldürülmesi ve bölge altyapısının tahrip olmasına yol açmakla kalmayıp, aynı zamanda sınır bölgelerinde yaşayan ve Ruslara sempati besleyen halka da zarar verdi. Sığınacak yeri olamayan yüzlerce Rus kökenli emekli öldü veya yaraland. Böylelikle bu yöntem, başlangıçta bağımsızlık yanlısı olmayanları bile Dudayev'in yanına itti. ${ }^{38}$

Başta ABD üzere Batılı güçlerin zorlamasıyla kendi kamuoyunun baskısı altında kalan Yeltsin'in ateşkes ve barış sağlama çabası, Çeçenlerin isteklerinden taviz vermemesi ve yerel Rus birlikleri üzerinde denetim kurulamaması sonucu başarıya ulaşamadı. ${ }^{39} \mathrm{Bu}$ başarısızlık, Yeltsin rejiminin içinde ve dişarıda imajının zedelenmesine neden olduğu gibi, Rus sivil hedeflerine yönelik terör eylemlerine yol açtı.

14 Haziran 1995 tarihinde, Şamil Basayev komutasındaki Çeçen gerillaları, Çeçenistan'a $110 \mathrm{~km}$. uzaklıktaki Rus kasabası Budennovsk'u basarak sivil halktan rehineler aldı. Başarısız kurtarma girişimleri sonrasında, Rus hükümeti gerillaların isteklerini kabul etti. Barış görüşmeleri başlatıldı ve eylemcilere serbest geçiş hakkı tanıdı. 20 Haziran'da gerillalar Rus takibini atlatarak güvenli bölgelere sığınmayı

\footnotetext{
${ }^{38}$ Rus ordusunun umulmadık başarısızlı̆̆ı ve içine düştüğü traji-komik durum bütün dünya ve Rusya'da büyük şaşkınlık yarattı. Bunun sebepleri ve savaşın gidişatına etkileri hakkında bkz. Benjamin S.Lambeth, "Russia's Wounded Military," Foreign Affairs, Cilt LXXIV/2, Mart-Nisan, 1995, ss. 86-98; Lieven, age, ss. 117-134; Bruce W. Nelan, "Why it all Went so very Wrong", Time, 16 Ocak 1995, ss. 21-22; Oleg Blotsky "Lessons not Learned", Time, 20 Şubat 1995, ss. 28-29; Raymond C.Finch, "Why the Russian Military Failed in Chechnya", Foreign Military Studies Office, http://call.army.mil/call/fmso/fmsopubs/issues/ yrusfail/yrusfail.htm, (Erişim Tarihi: 10 Temmuz 2000); Charles W. Blandy, "Military Aspects of the Two Russo-Chechen Conflicts in Recent Times", Central Asian Survey, Cilt XXII/4, Aralik 2003, ss. 424-427.

39 Devam eden savaş, Rus ekonomisine ve reformlarına da ağır darbe vurdu. Aylık enflasyon \%16'yı geçti. "Chechnya Bombardment Renewed”, Facts on File, Cilt LV/2828, 9 Şubat 1995, ss. 95; "Chechnya Truce Reached, Broken”, Facts on File, Cilt LV/2830, 23 Şubat 1995, s. 133; Aldıkları uyuşturucu ve alkol sonucu denetimden çıkan Rus birlikleri, 7-10 Nisan tarihlerinde Samashki kentinde silahsız sivil halkı katletti. Olayın televizyonlara yansıması, Rus hükümetini içeride ve dışarıda zor durumda bıraktı. "Samashki Raid Targeted Civilians", Facts on File, Cilt LV/2841, 11 Mayıs 1995.
} 

başarısızlığı içeride ve dışarıda Rus prestijine ağır darbe oldu. Rus

Stratejileri

Y11: 14

Sayı: 28

kamuoyu başından beri istemediği savaşın bir an önce sona erdirilmesini talep etmekteydi. ${ }^{40}$

Budennovsk eylemi sonrasındaki ateşkes ve barış çabaları her iki tarafta da umut yaratsa da sonuçsuz kaldı. ${ }^{41}$ Çeçen gerilla eylemleri ile Rusların karşı-gerilla harekâtı değișen şiddet ve fasılalarla devam etti. 20 Ağustos 1995 'teki küçük çaplı Argun baskını sonrasında, ${ }^{42}$ Çeçen gerillalar, 9 Ocak 1996'da Dağıstan'ın Kızılyar kasabasını bastı. İsteklerinin Rusların Çeçenistan'ı boşaltması olarak duyuran gerillalara, görüşmeler sonrasında, serbest geçiş hakkı tanındı. Ancak Çeçenistan sınırı yakınlarındaki Pervomayskoye köyünde Rus birlikleri taarruza geçti. 17 Ocak'a kadar devam eden kuşatma esnasında Rusların rehineleri kurtarma çabası sonuçsuz kaldı. Budenovsk benzeri bir fiyasko yaşanması korkusuyla, köy yoğun bombardımana tabii tutuldu. Sonuçta gerillalar kaçmayı başardı. Onlarca rehine ve köylü öldürüldü. Ruslar bir kez daha utanç verici başarısızlığa uğradı. Üstelik eyleme müdahalenin idaresindeki bu becerisizlik, müteakip Çeçen misillemelerine uygun ortam yarattığı gibi, başlangıçta Çeçenlerin yanında yer almayan Kuzey Kafkasya kamuoyunun ciddi bir kısmını Çeçen yanlısı haline getirdi. ${ }^{43}$

\footnotetext{
${ }^{40}$ Eylem esnasında Kanada'daki G-7 toplantısında bulunan Yeltsin çok zor durumda kaldı ve Batılıların ağır eleştirilerine uğradı. Smith, age, s. 200-203; "Chechen Rebels Release Hostages After Raid on Russian Town", Facts on File, c. 55, no. 5847, 22 Haziran 1995, s. 441-442. Rus meclisi Duma, hükümetin eylemi bastırmaktaki beceriksizliğinden dolay1 güvensizlik oyu vererek "Savaş Partisi" üyelerinden bazılarının istifasına neden oldu. "Chechen Hostage Crisis", Keesing's Record of Word Events, Cilt XLIV/6, 24 Haziran 1995, ss. 40608-40609.

${ }^{41} 30$ Temmuz 1995 ateşkes antlaşması hakkında bkz. John Kohan, "Halfway to Peace", Time, 14 Ağustos 1995, s. 20; "Russia, Chechnya Reach Truce in Secession Conflict", Facts on File, Cilt LV/2853, 3 Ağustos 1995, s. 558.

${ }^{42}$ Ruslar, gerillaları yoğun topçu bombardımanı sonrasında Argun'dan atabildi. Keesings Record of World Events, Cilt XLI/718, 15 Eylül 1995.

${ }^{43}$ Lieven, age, ss. 137-139; Smith, age, ss. 210-216; James O.Jackson, "Pale, Rested and Ready", Time, 22 Ocak 1996, ss. 24-25; Michael S. Serrill, "Blown Away", Time, 29 Ocak 1996, ss. 11-15; "Russia Capture Chechen - Held Village: Many Hostages Freed After
} 
Taraflar arasındaki barış görüşmeleri, Avrupa Güvenlik ve İşbirliği Teşkilatı'nın (AGIT) aracılığıyla devam etse de, Rus komutanlarına yönelik kimin yaptığı belirsiz terörist saldırıları, Rus birliklerinin tedhiş ve yıkım faaliyetlerine devam etmesi ve karş1lıklı güvensizlik sonucu başarılı olamadı. Askerî harekât ile elde edilemeyen başarıyı daha kolay yoldan sağlama fikriyle Rus birlikleri bütün çabalarını Çeçen direnişinin liderlerine yöneltti. Uzun uğraşılar sonrasında 21 Nisan 1996'da Cahar Dudayev, Gekhi-Chu köyü yakınlarında düzenlenen bir füze saldırısı sonucu öldürüldü. ${ }^{44}$ Ancak Rus siyasi ve askerî liderleri, bu saldırının ardından da arzu ettikleri gibi Çeçen direnişini kıramadı.

Yeltsin, barış görüşmeleri ve askerî harekâtın akılcı bir birleşimi sayesinde, yeniden devlet başkanı seçilmeyi başardı. Fakat Yeltsin'in bu sonuca varmak için yaptığı manevralar ve çıkan barış fırsatlarını tepmesi, sorunu iyice içinden çıkılmaz bir hale getirdi. Tıpkı Rus Çarllğ 1 döneminde olduğu gibi, iç politik çıkarlar ve şahsi menfaatler için ülkenin menfaatleri düşüncesizce harcanmaktaydı. Aslında yeni Rus liderliğinin sorumsuz Rus çarlarından hiçbir farkı yoktu. ${ }^{45}$

Yeltsin, seçim zaferini kutlama firsatı bulamadan, 6 Ağustos 1996 tarihinde Çeçen savaşçıları başarılı bir şekilde Grozny'ye sızmayı başardı. Şamil Basayev komutasındaki gerillalar kendilerinden sayıca ve silahça kuvvetli Rus birliklerini kuşatıp kademeli bir şekilde imha etmeye başladı. Yardıma gelmeye çalışan Rus zırhlı birlikleri yoğun saldırı ve koordineli pusular yüzünden ağır zayiat vererek durmak zorunda kaldı. Rus ordusunun başarısızlığı, 11 Ağustos'ta Güvenlik Konseyi Sekreteri Aleksander Lebed'in aracılığıyla ateşkes görüşmelerinin

Massive Bombardment" Facts on File, Cilt LVI/2876, 18 Ocak, 1996, ss. 17-18. Dağıstan'da sivil halkın içine düştüğü yılgınlık ve Rus karşıtllğı hakkında bkz. Michael S.Serrill, "Morning After the Teror", Time, 5 Şubat 1996, s. 19.

${ }^{44}$ Smith, age, ss. 230-232; Gall, Waal, age., ss. 318-319; "Path to Political Settlement in Chechnya", Nisan 1997, http://www.amina.com, (Erişim Tarihi: 9 Mart 2000); Maria Eismont, "Djohar Dudaev: Dead or Alive? Was He Killed Intentionally?", 3 Mayis 1996, http://www. amina.com/ article/politics.shtml, (Erişim Tarihi: 9 Mart 2000).

${ }^{45}$ Blank, Yeltsin's Folly..., age, ss. 94, 100-101; Smith, age, ss. 237-239. 
296

Güvenlik Stratejileri

Y11: 14

Sayı: 28

başlatılmasına yol açtı. Ateşkes anlaşması 31 Ağustos'ta Khasavyurt'ta imzalandı ve 12 Mayıs 1997 Moskova Barış Antlaşması ile teyit edildi. 23 Kasım'da son Rus birliklerinin çekilmesiyle, Çeçenlerin kesin zaferi tamamlanmış oldu. ${ }^{46}$

Birinci Çeçen Savaşı, Soğuk Savaş sonrası dönemin en kanlı iç savaşı konumundadır. Her iki taraf da temel savaş kurallarını dikkate almayarak sivil halk ve savaş dişı olanlara yönelik ciddi insan hakkı ihlallerine sebebiyet vermişlerdir. Özellikle Rus birliklerinin yerleşim yerlerine karşı ağır silah kullanması ve sivil halka yönelik tedhiş harekâtına girişmesi sonucu binlerce kişi ölmüş, yaralanmış veya mülteci konumuna düşmüştür. Yerleşim yerleri ve altyap1 büyük ölçüde tahrip olmuştur. Sanayi tesisleri ve tarım alanlarının bir kısmı kullanılamaz hale gelmiştir. Dünya kamuoyu Çeçenlere karşı büyük sempati duymasına rağmen somut olarak pek bir şey yapılmamıştır. ${ }^{47}$

27 Ocak 1997 tarihinde AGIT gözetiminde icra edilen seçimler sonucunda, Sovyet eski Albayı Aslan Maskhadov, Çeçenistan Devlet Başkanı seçildi. Uzun ve ağır tahribata yol açan savaşa ve binlerce ölü ve yaralıya rağmen, Çeçenler 1lımlı ve pragmatik Maskhadov'u savaş kahraman1, karizmatik ancak radikal Şamil Basayev'e tercih etti. Bu tercih, halkın hâlâ normal hayata dönülebileceği umudu taşıdığının ve her tür aşırıllığa karşı olduğunun en önemli belirtisiydi. ${ }^{48}$

Maskhadov kendisinin seçilmesine neden olan barış, güvenlik ve ekonomik-sosyal refah beklentilerini karşılayamadı. Rusya ile kalıcı

${ }^{46}$ Gall, Waal, age., s. 331-361; Smith, age, s. 244-250; Anatol Lieven, "Freedom and Anarchy, Russia Stumbles Toward the Twenty-First Century", http://www.amina.com/ article/politics.shtml, (Erişim Tarihi: 9 MART 2000).

47 Tarafların Birinci Çeçen Savaşı'nda verdikleri kayıpları konusunda elde kesin veriler bulunmamaktadır. Mevcut veriler çerçevesinde yapılan muhafazakâr bir tahmine göre; 7500 Rus askeri, 4000 Çeçen gerilla ve 35.000 sivil ölmüştür. John B. Dunlop, "How Many Soldiers and Civilians Died during the Russo-Chechen War of 1994-1996?", Central Asian Survey, Cilt XIX/3-4, 2000, s. 338; Svante E. Cornell, "International Reactions to Massive Human Rights Violations: The Case of Chechnya", Europe-Asia Studies, Cilt LI/1, Ocak 1999, ss. 85-97.

${ }^{48}$ Gall, Waal, age., ss. 362-371; Smith, age, ss. 259-267; Elsmont, age. 
barış tesisini ve Çeçenistan'ın bağımsız devlet olarak uluslararası kamuoyunda kabul edilmesini sağlayamadi. Maskhadov, üstelik klan reislerini ve Basayev benzeri kendi şahsi milis kuvvetlerine sahip gerilla liderlerini denetimi altına alamadı. Tam tersine, zaman içinde ülke yönetimini onlara terk etmek zorunda kaldı. Kanunsuzluk kanun haline geldi. Ülkenin geleceği açısından önemli yabancı yardım kurumu görevleri, iş adamları ve hatta diplomatlar fidye için kaçırıldı. Ülke, Dudayev döneminin de ötesinde suç cennetine dönüştü. ${ }^{49}$

$\mathrm{Bu}$ gelişmelere paralel bir şekilde, başta Suudi Arabistan ve Körfez ülkeleri destekli Vahabi tarikatı olmak üzere aşırı İslamcı akımlar Çeçenistan'da güç kazanmaya başladı. Bu durumda ilkbahar 1994 tarihinden itibaren Pakistan bağlantısı sayesinde Şamil Basayev grubu ve lider konumundaki gerillaların Afganistan'da askerî ve siyasi eğitim görmesinin önemli rolü oldu. Aynı yıl ilk yabancı gönüllüler Çeçenistan'a ulaştı. Bunlar, geçmişteki sayıca önemsiz maceracılardan farklı olarak, örgütlü, mali ve personel desteğine sahip gruplardı. 1995 y1lında ise İran ve Sudan destekli gruplar Çeçenistan'da yer edinme çabasına girdi. Çeçenistan bir bakıma farklı radikal İslamcı devlet ve grupların güç mücadelesi alanı haline geldi. Sonradan Körfez grubu adını alan ve geçmişte Ürdün-Suudi Arabistan kökenli Habib Abdülrahman Hattab'ın liderliğini yaptığı grup, en önemli savaşçı kesimi teşkil etmekteydi. Mağribi grubu (Cezayir, Tunus, Fas kökenliler) ise

\footnotetext{
${ }^{49}$ Bruno Coppieters, "Secession and War: A Moral Analysis of the Russian-Chechen Conflict", Central Asian Survey, Cilt XXIII/4, Aralık 2003, s. 386-390; Georgi M. Derlyguian, "Che Guevaras in Turbans", New Left Review, no. 237, Eylül-Ekim 1999, s. 48; Maxim Byshchovets, "A Serene Sky Over Ichkeria", http://www.amina.com/ article/ politics.shtml, (Erişim Tarihi: 9 Mart 2000). Suç çeteleri salt parasal çıkarlarla ilgili değildi. Çoğu zaman politik hesaplar için de görev alıyorlardı. Buna iyi bir örnek, mevcut yönetimin muhalifi Ruslan Hasbulatov'un kardeşinin kaçırılarak gözdağı verilmesidir. Aleksandr Yevtushenko, "Interview with Ruslan Khasbulatov", February 25, 1998, http://www.amina.com/ article/politics.shtml, (Erişim Tarihi: 9 Mart 2000); Radikal İslamcı akımlar güç kazandıkça daha aleni bir şekilde suç işlenmeye başlandı. İslam, suç çetelerine arzu ettikleri kılıfi sağladı. Albert Digaev, "Speaking About Kidnapping", http://www.amina.com/ article/politics.shtml, (Erişim Tarihi: 9 Mart 2000).
} 
298

Güvenlik Stratejileri

Y11: 14

Sayı: 28

ikinci önemli gruptu. Ancak şunu da eklemek gerekir ki, Rus medyasının aktardığı yüzlerce radikal İslamcı yabancı militan iddiaları doğru değildir. Çeçenistan'daki yabancı İslamcıların sayısı 300'ü geçmemiştir. Zaten Çeçenler için önemli olan, yabancı gönüllülerden ziyade mali destektir. ${ }^{50}$

Kısacası, Çeçenler ellerine geçen firsatı kaçırdı. Mücadelelerinin bir halkın kendi kaderini tayin hakkı talebi ve millî bağımsızlık savaşı olduğunu dünya kamuoyuna gösteremediler. Suç çeteleri ve İslamc1 gruplar, var olan gergin ortamı daha da kötüleştirerek normal hayata geçmek isteyen ılımlı halkın çabalarını önledi. Ancak bunda Rusya'nın baskıları ve çözümden kaçınması ile uluslararası kamuoyunun Çeçenistan'a somut destekte bulunmamasının da önemli rolü olduğunu unutulmamalıdır.

\section{Dağıstan Saldırısı ve İkinci Çeçen Savaşı (1999-2009)}

Şamil Basayev ve Hattab komutasındaki 1500 İslamcı militan 7 Ağustos 1999 tarihinde Dağıstan'a saldırdı ve Botlikh-Tsumadin bölgesinde beş köyü işgal etti. Bu saldırı ile 1994 yılında Çeçenistan'ın Rus birliklerine işgaliyle başlayan sorun yepyeni bir çehre kazandı. Artık saldırgan rolünü Çeçenler üstlenmekteydi. ${ }^{51}$

Aslında bu beklenmesi gereken bir hareketti. Dağıstan eskiden beri Kuzey Kafkasya bağımsızlık hareketlerinin önemli bir merkezi ve mücadele alanıydı. Dağıstan mücadelenin insan kaynağı ve liderlerini sağladığı gibi Hazar sahilleri vasıtasıyla dışarıya açılan kapısıydı.

50 Kuzey Kafkasya'da dinî akımlar isyan-bağımsızlık hareketlerinde ön planda bulunmuştur. 1785-1759 arasında Nakşibendi tarikatı Müridizm kolu, 1861-1890 arasında Kadiri tarikatı isyanların lider kadrosunu teşkil etmiştir. David Damrel, "The Religious Roots of Conflict: Russia and Chechnya", http: //www.amina.com/ article/politics.shtml, (Erişim Tarihi: 9 Mart 2000); Ancak şu an hakim olan dinî akımlar dış destek kaynaklıdır. Yossef Bodansky, "Chechnya: The Mujahedin Factor", January 1998, http://www.amina.com/, (Erişim Tarihi: 9 Mart 2000); Vahabi tarikatının kökeni ve temel özellikleri hakkında bkz. "Rise of the Wahabi Movement", http://www.amina.com/ article/politics.shtml, (Erişim Tarihi: 9 Mart 2000);Derlyguian, age, ss. 7-11.

${ }^{51}$ Yuri Zarakhovich, "A Nightmare War in a Remote Land", Time, 23 Ağustos 1999, s. 14; Derlyguian, age, s. 3. 
Dolayısıyla Dağıstansız bir mücadele pek mümkün gözükmüyordu. Üstelik Mayıs 1995'te yerel radikal İslamcılar ayaklanıp birkaç dă köyünün kontrolünü ele geçirmiş ve hükümet güçleriyle çarpışmıştı. Ancak 1921 yılından bu yana Dağıstan'da çok şey değişmişti. İlk olarak, Dağıstan'ın etnik yapısı iyice karışmıştı. 2,5 milyon nüfusu olan cumhuriyette 30 'dan fazla etnik grup bulunmaktaydı. İkinci olarak da Çeçenistan'ın başına gelenler ve içinde bulunduğu anarşik ortam Dağıstanlılara pek cazip gözükmüyordu. Son olarak, Dağıstan'da da etkinlik kazanan suç çeteleri ve İslamcı akımlar hiç de hoş görülmüyordu. Eski komünist günlere duyulan özlem, ciddi bir kesimce paylaşılmaktayd ${ }^{52}$

Che Guevara tarzı bir devrimi ihraç etme amaçlı saldırı, büyük umutlarla başlasa da sonuçsuz kaldı. İslamcı militanlar birkaç sınır köyünü işgal etmekten öteye gidemediler. Bekledikleri halk desteğini alamadıkları gibi, tahminlerinin ötesinde Rus taarruzuna maruz kaldılar. Bu da yetmezmiş gibi, 4-16 Eylül 1999 tarihleri arasında Moskova, Buynaksk ve Volgodonsk şehirlerinde sıradan apartmanları hedef alan bir seri bombalama eylemi gerçekleştirildi ve 300'den fazla sivil hayatını kaybetti. Belli başlı bütün Çeçen grupları ve hatta Hattab gibi yabancı militanlar, bu eylemlerin sorumluluğunu reddetse de, doğru düzgün bir olay yeri incelemesi bile yapmadan Rus güvenlik güçleri Çeçenleri sorumlu tuttu. Dağıstan saldırısı ve doğrudan sivilleri hedef alan bombalama eylemleri Rusya'da bütün iç dengeleri altüst etti. Federasyonun çözüleceği paranoyası dirildi. Dağıstan'ın kaybı, ülkenin Hazar sahillerinin önemli bir kısmının yitirilmesinin yanı sıra, diğer özerk cumhuriyetlerin de bir anda kaybedileceği endişesini doğurdu. Sonraları bazı yorumcular, üst üste gelen bu eylemleri, El Kaide'nin Amerika'daki terör saldırılarına atfen "Rusya'nın 9/11'i” diye adlandırmıştır. $\mathrm{Bu}$ saldırı, iktidar mücadelesinin yoğunlaştığı Kremlin politikacılarına yeni bir olanak tanıdı. Henüz yeni başbakan olarak

\footnotetext{
${ }^{52}$ Enver Kisriev, Robert Bruce Ware, "Conflict and Catharsis: A Report on Developments in Dagestan Following the Incursions of August and September 1999", Nationalities Papers, Cilt XXVIII/3, 2000, ss. 479-487; Zarakhovich, age, s. 14; Derlyguian, age, ss. 11-17.
} 
atanmış olan Vladimir Putin, teröre karşı Rus halkının gösterdiği tepki

Güvenlik Stratejileri

Y11: 14

Say1: 28 ve korkuyu kendisini başkanlığa taşıyacak bir firsat olarak gördü. Bunun için Putin'in kısa zamanda ve kesin olarak kazanılacak bir Çeçenistan zaferine ihtiyacı vardı. Böylelikle, Basayev ve Hattab, ummadıkları bir tepkiyle karşılaşıp kısa bir direniş sonrasında Çeçenistan'a geri çekilmek zorunda kaldı. ${ }^{53}$

Rus birlikleri 29 Eylül 1999 başında doğudan ve kuzeyden Çeçenistan'a girmeye başladı. Yeni Rus işgali eskisinden büyük ölçüde farklıydı. Rus ordusunun 1994-96 Savaşı'ndan deneyim kazandığı ve NATO'nun Kosova harekâtından etkilendiği anlaşılmaktaydı. İlk olarak, etkin bir kamuoyu oluşturma ve medya kampanyası ile Rus halkının önemli bir kesiminin desteği sağlandı ve bu destek harekât boyunca korunmaya çalışıldı. Denetim altındaki medya kuruluşları dışındaki basın organları harekât bölgesine alınmadığı gibi, bölgedeki bütün iletişim denetim altında tutuldu. İkinci olarak, harekâtın politik ve askerî açıdan tek bir merkez ve komuta altında idaresi tesis edildi. Bütün askerî ve sivil kurumlar kendi emir-komuta sistemleri içinde doğrudan Başbakan Vladimir Putin'e bağlı olarak faaliyetlerini icra etti. Üçüncü olarak, ordu ve polis teşkilatının seçme ve eğitimli birlikleri harekât için tahsis edildi. Bu birlikler mevcut en iyi silah ve teçhizatla donatıldı. Ayrıca Rusya ortalamasının üstünde maaş ve ikramiye ile bağl1lık ve savaş azimleri arttırılmaya çalışıldı. Dördüncü olarak, piyade birliklerinin doğrudan kullanımından mümkün olduğunca kaçınıldı. Bunun yerine, hava kuvvetleri, topçu ve havan silahları ile düşman direnişinin tamamen yok edilmesi ve ancak bu aşamadan sonra fiilen işgal faaliyetinin başlatılması yöntemi tercih edildi. Beşinci olarak, Rus kamuoyunun en önemli endişesi olan zayiat rakamları, ölülerin ve yaralıların tahliyesi ve cenaze törenleri büyük bir denetim ve gizlilik altında icra edildi. Bizzat harekâtın içinde bulunan birlikler ve komutanları bile gerçek zayiat rakamlarını bilmemekteydi. Altıncı

${ }^{53}$ Smith, age, ss. xxv-xxx; Blandy, age, ss. 427-429; Zarakhovich, age., s. 14; Paul QuinnJudge, "Back into The Inferno", Time, 11 Ekim 1999, ss. 24, 26; Rod Usher, "Russia's Brass from the Past", Time, 22 Kasim 1999, ss. 24-25. 
olarak, büyük paralar harcanarak Çeçenler ve komşu halklardan iş birlikçi unsurlar kazanılmaya çalışıldı. Bu çabaya harekât boyunca devam edilirken, mafya ve diğer suç örgütleri ile ilişki kurmaktan kaçınılmadı. Son olarak, etkin bir dış kampanya ile uluslararası kamuoyu ve Çeçenlere sempati duyan devletler baskı altına alınmaya çalışıldı. Maddi ve manevi yardımların önüne geçilmeye çalışıldı. Kısacası, en kısa sürede ve kesin zafer kazanmak, tek amaçtı. Bu amaca ulaşmak için her şeyi yapmak serbestti. ${ }^{54}$

Rus birlikleri fazla zorlanmadan Çeçen direnişini kırarak büyük yerleşim yerlerini ele geçirmeyi başardı. Nihai taarruz öncesi ağır silahlarla dövülen şehirlerde yüzlerce sivil öldü. ${ }^{55} \mathrm{Bu}$ başarı, aynı zamanda Putin'in Rusya Federasyonu Devlet Başkanlığı makamına çıkmasını sağladı. ${ }^{56}$ Ancak şehirleri kaybederek hareket serbestisi kazanan Çeçen gerillalar, Rus birliklerine yönelik geniş çapta bir gerilla savaşı başlattı. Rus birlikleri, geçmişte olduğu gibi, gerilla saldırılarıyla baş edemedi. Gerillalara yardım ve yataklık ettiği düşünülen yerleşim yerleri ağır silahlarla bombalandı. Sivil halk çeşitli askerî ve polisiye tedbirlerle denetim altına alınmaya çalışıldı. Ancak bu uygulamalar esnasında temel insan haklarına bile özen gösterilmedi. Yüzlerce kişi herhangi bir yargilamaya tabi tutulmadan hapishanelere atıldi; bunlardan birçoğu da daha sonra kayboldu. Binlerce kişi komşu ülke ve bölgelere sığınmak zorunda kaldı. Devlet memuriyeti dışında yasal

\footnotetext{
${ }^{54}$ Quinn-Judge, age., s. 24-26; Paul Quinn-Judge, "War Clouds Over Chechnya", Time, 25 Ekim, 1999, ss. 34-35; Yuri Zarakhovich, "The Empire Strikes Back", Time, 1 Kasım, 1999, s. 28; Paul Quinn-Judge, "Russia Rolls in for War 2K", Time, 29 Kasım, 1999, ss. 22-23; Paul Quinn-Judge, "Chechen Hell", Time, 6 Aralık 1999, s. 21-24; Paul QuinnJudge, "Hard Lessons", Time, 27 Aralık 1999, ss. 24-25; Graeme P. Herd, "The RussoChechen Information Warfare and 9/11: Al-Qaeda throught the South Caucasus Looking Glass?", (ed.) Rick Fawn, Realignments in Russian Foreign Policy, Frank Cass, London, 2002, ss. 110-112.

${ }_{55}$ Paul Quinn-Judge, “The Fatal Frontier”, Time, 1 Kasım 1999, ss. 26-28.

${ }^{56}$ Andrew Meier, Paul Quinn-Judge, "War Clouds Over Chechnya", Time, 17 Ocak 2000, ss. 20-22; Paul Quinn-Judge, "Man with a Mission”, Time, 27 Mart 2000, ss. 28-31; Coppieters, age, s. 391.
} 
Güvenlik Stratejileri

Y11: 14

Sayı: 28

bir gelir kaynağı kalmadığı için Çeçenistan'da kalanlar büyük bir ekonomik sefalet içine düştü. ${ }^{57}$

Ruslar bir kez daha Yermelov, Voronzov ve Yeltsin'in çözüm sağlamayan askerî gücün hedef gözetilmeden kullanılması açmazına düşmüş gözüküyorlardı. İşte tam o noktada, Putin, zamanında Bariatinsky'nin uyguladığı stratejinin önemli bir parçası olan yerel iş birlikçiler edinip bunların askerî gücü ve yerel bağlantılarından istifadeyi uygulamaya soktu. Çeçen halkının bahtsızlığı, Putin'in halkı kazanmak için herhangi bir niyet ve programının olmamasıdır. Yukarıda belirttiğimiz gibi, Çeçenistan'da radikal İslamcılığının ve suç örgütlerinin güç kazanması yerel liderlerden bir kısmınca ve halkın çoğunluğunca hoş karşılanmamıştı. Ruslara karşı cihat fetvasını imzalayan eski Baş Müftü Akhmed Kadyrov, en kayda değer muhalifti. Radikal grupların öldürmeye çalıștığı Kadyrov, Putin'in açılımını değerlendirerek Rus saflarına katıldı. Salt din adamlığı yapmayıp aktif bir şekilde savaşa katıldığı için araziyi ve Çeçen direnişin güçlü ve zayıf taraflarını çok iyi biliyordu. Önce kendi akrabalarını ve klanını, müteakiben de diğer hoşnutsuz kitleyi yanına çekmeyi başardı. Rus askerlerin aksine, kadyrovtsky ismiyle anılan Kadyrov milisleri, gerillaları ve onlara destek veren sivilleri kolaylıkla tespit edebilmekteydi. Ayrıca para ve diğer vaatlere itibar etmeyenleri kendi yanlarına çekmek için tehdit ve aile üyeleri vasıtasıyla şantaj gibi yöntemleri uygulamaktan da çekinmediler. Boyun eğmeyenlerin akrabaları infaz edildi. Kadyrov, bu tarz infazların icrasında grubuna yeni katılanları kullanmaktaydı. Amacı katil ile maktulün aileleri arasında kan davası başlatmaktı. ${ }^{58}$

${ }^{57}$ Paul Quinn-Judge, "Fear and Loathing", Time, 6 Mart 2000, ss. 18-19; Anonim, "What Life is Like in Chechnya under the Russian Occupation- the Realities of Today's Chechnya", Central Asian Survey, Cilt XXII/4, Aralık 2003, ss. 459-464.

58 John Russell, "Chechen Elites: Control, Cooption or Substitution?", Europe-Asia Studies, Cilt LXIII/6, Ağustos 2011, ss. 1079-1081; Jean-François Ratelle, Emil Aslan Souleimanov, "A Perfect Counterinsurgency? Making Sense of Moscow's Policy of Chechenisation", Europe-Asia Studies, Cilt LXVIII/8, Ekim 2016, ss. 1294-1300 
Putin, sadece Kadyrov'u değil, başka Çeçen liderleri de yanına çekmiş ve onların da milis gruplar kurmalarını desteklemişti. Ancak bunlardan hiçbiri Akhmed Kadyrov kadar taraftar toplayıp başarılı olamadı. Çeçen milisler başarı kazandıkça, Putin karşı gerilla savaşının asıl sorumluluğunu yavaş yavaş Kadyrov'a ve diğerlerine devretmeye başladi. Rus birlikler ateş, hava, muhabere ve lojistik desteği verip ve ayrıca hudut güvenliğini üstlenip geri kalan "pis" işleri Çeçenlere devretti. Savaşın "Çeçenleştirilmesi"yle, yani ölen ve öldürülenlerin Çeçen olmasıyla, mücadele yeni bir evreye girdi. Zaten dağılmış konumdaki Çeçen direnişi iyice parçaland. Haziran 2000'de Kadyrov yeni Çeçen yönetiminin başına getirildi ama kendisine başkan unvanı ancak Ekim 2003 seçimi sonrasında verilecekti. Çeçenleştirme projesinin başarı kazanmasında en önemli hususlardan biri, hiç şüphesiz Rusya'nın Kadyrov'a ciddi miktarda mali kaynak aktarmasıdır. Bu sayede, Rusya rejimini destekleyen gruplar cömertçe ödüllendirilmiştir. ${ }^{59}$

Çeçenistan'ın tek aklıselim ve 1lımlı lideri Maskhadov'un Mart 2003 tarihli barış çağrısı, ${ }^{60}$ her iki tarafta da etkisiz kaldı ve kendisi de 8 Mart 2005'te düzenlene bir operasyonda öldürüldü. Çeçenler, İslamc1 liderlerin önderliğinde, aralarında herhangi bir emir-komuta ilişkisi bulunmayan çetelere bölündü. Şiddetten başka çözüm göremeyen bu çeteler, önce Rus güvenlik güçlerine ve onlarla iş birliği yapan yerli unsurlara karşı vurkaç esaslı saldırılar icra ettiler. Geçmişten farklı olarak, bu saldırılar bütün vahşeti ile filme alınarak dünya kamuoyuna duyuruldu. Müteakiben, Arap teröristlerden etkilenerek askerî ve sivil hedeflere karşı intihar saldırılanı düzenlenmeye başlanıldı. ${ }^{61}$

7 Haziran 2000'de kayda geçen ilk intihar saldırısında iki polis; 2-3 Temmuz 2000'de de koordineli beş ayrı intihar saldırısı ile yüze yakın güvenlik görevlisi öldürüldü. Askerî hedeflere yönelik intihar saldırılarını, kısa süre sonra, Çeçenistan içinde ve dışında sivil halkı

\footnotetext{
${ }^{59}$ Ratelle, Souleimanov, age, ss. 1295-1296, 1299-1300; Russell, age, s. 1080.

${ }^{60}$ Ilyas Akhmadov, "The Russian-Chechen Tragedy: The Way to Peace and Democracy”, Central Asian Survey, Cilt XXII/4, Aralık 2003, ss. 481-509.

${ }^{61}$ Blandy, age, ss. 430-431.
} 
304

Güvenlik Stratejileri

Y11: 14

Sayı: 28

hedef alan saldırılar izledi. 8 Ağustos 2000'de Moskova'da bir otobüse yönelik eylemde sekiz kişi ölürken 5 Temmuz 2003'te bir konseri hedef alan iki saldırıda 15 kişi öldü ve 60 kişi yaralandı. İntihar saldırılarında doruk noktasına 24 Ağustos 2004'te iki Rus yolcu uçağının uçuş esnasında infilak ettirilmesiyle ulaşıldı. İntihar saldırılarında saldırganların çoğunlukla kadın olması, dikkate değer bir olgudur. ${ }^{62}$ Savaş nedeniyle dul kaldıklarını iddia eden bu kadınlar, artık bütün klasik sınırlamaların ortadan kalkmasına ve savaşın yarattığı sosyal yozlaşma ve tahribata iyi bir örnek teşkil etmektedirler. ${ }^{63}$

Rus yönetimi açısından en kötü eylem ise 9 Mayıs 2004'te gerçekleşti. Grozny stadyumunda düzenlenen bir tören esnasında şeref locasının altına yerleştirilen bombanın infilak ettirilmesiyle Rusya'nın en değerli müttefiki Akhmed Kadyrov ve onlarca üst düzey yönetici öldürüldü. Kısa bir süre için, bütün dengelerin isyancılar lehine bozulacağı ve Çeçen iş birlikçilerin etkinliğini yitireceği beklentisi içine girildi. Öldürülen başkanın Akhmed Kadyrov'un oğlu Ramzan Kadyrov, oldukça genç olmasına rağmen babasının mirasına sahip çıktı. Putin tarafından asaleten başkan atandığı Şubat 2007'ye kadar fiilen başkanlığ 1 ve milis komutanlığını yürüten Ramzan Kadyrov, babasından farklı olarak, Putin'le ve diğer önemli Rus liderlerle sıkı ilişki kurmayı başardı. Konumunu sağlamlaştırmak için, hem muhafazakâr İslam kartını iyi oynad1, hem de organize suç örgütleriyle sıkı ilişkiler geliştirdi. Rusya'dan akmaya devam eden mali kaynaklarla babası gibi sadece taraftarlarını zengin etmedi; aynı zamanda başta Grozny olmak üzere büyük şehirleri ve ülke altyapısını yeniden inşa etmeye başladı. Büyük

62 "Russian suicide blast: Dozens dead", CNN World News, 4 Ağustos 2003, http://edition.cnn.com/ 2003/WORLD/europe/08/01/russia.blast/index.html, (Erişim Tarihi: 9 Eylül 2004); "Moscow metro blast kills 39", CNN World News, 6 Şubat bomber kills 9", CNN World News, 1 Eylül 2004, http://edition.cnn.com/2004/ WORLD/ europe/08/31/russia.carblast/index.html, (Erişim Tarihi: 9 Eylül 2004); "Explosions 'led to Russia crashes"', CNN World News, 30 Ağustos 2004, http://edition.cnn.com/2004/ WORLD/europe/08/30/russia.planecrash/index.html, (Erişim Tarihi: 9 Eylül 2004).

${ }^{63}$ Savaşın Çeçen toplumunu yozlaştırıp radikalleştirdiği bazı Çeçen liderler tarafindan da kabul edilmektedir. Akhmadov, age, ss. 487-488. 
inşa projeleri sayesinde sıradan halk da düzenli para kazanmaya başladı. Ramzan Kadyrov, 16 Ekim 2008'de Grozny'de babasının adını taşıyan Avrupa'nın en büyük camisinin açılışını yaptı. Ülke genelinde çok sayıda cami ve mescit inşa ettirdiği gibi, Kuran kursları açtı, kendisini destekleyen din adamlarını paraya boğdu. ${ }^{64}$

Kadyrov ailesi, yavaş fakat kendinden emin bir şekilde, Çeçenistan'a hâkim olurken, Çeçen gerillalar bir taraftan intihar saldırısı gibi yepyeni bir yöntemi uygulamaya, bir taraftan da Budennosk benzeri toplulukları rehin alma eylemlerine devam ettiler. 23 Ekim 2002'de Moskova'daki bir tiyatro salonunda yüzlerce seyirci 50 silahlı Çeçen tarafindan rehin alındı. Rus güvenlik güçleri, üç gün süren kuşatma sonrasında kalkıştıkları oldukça başarısız kurtarma operasyonu esnasında, 115 rehinenin ölümüne neden oldu. 27 Aralık 2002'de Grozny hükümet konağına ve 22 Temmuz 2004'te İnguş Cumhuriyeti İçişleri Bakanlığına yönelik eylemlerde onlarca kişi öldü. Ancak en tartı̧̧malı ve rahatsız edici eylem, Kuzey Osetya Özerk Cumhuriyeti başkenti Beslan'da bir okulu hedef alan 1 Eylül 2004 tarihli baskındır. Okulda yüzlerce öğrenci ve öğrenci yakını rehin alındı. Eylemciler binaya patlayıcılar döşedi. Üç gün devam eden kuşatma sonrasında kendiliğinden ve gelişigüzel düzenlenen kurtarma operasyonunda çoğu çocuk 335 kişi öldü. ${ }^{6.5}$

Bu kanlı rehin alma eylemleri ve intihar saldırıları, ABD'yi hedef alan 11 Eylül saldırıları ile zaten hassaslaşmış olan dünya kamuoyunda Çeçenlere yönelik sempatiyi büyük ölçüde yok etti ve Rusya'ya Çeçenistan'da uyguladığı askerî yöntemleri haklı gösterme firsatı verdi.

\footnotetext{
${ }^{64}$ Ratelle, Souleimanov, age, ss. 1301-1307; Russell, age, ss. 1081-1082.

65 "Timeline: Russia terror attacks", CNN World News, 2 Eylül 2004, http://edition.cnn. com/2004/WORLD/europe/09/01/russia.timeline/index.html, (Erişim Tarihi: 9 Eylül 2004); "Gas killed 115 Moscow hostages", CNN World News, 27 Ekim 2002, http://edition.cnn. com/2002/WORLD/europe/10/27/moscow.deaths/index.html, (Erişim Tarihi: 9 Eylül 2004); "Toll rises from Russia attack", CNN World News, 23 Haziran 2004 http://edition. cnn. com/2004/WORLD/ europe/06/23/russia.toll/index.html, (Erişim Tarihi: 9 Eylül 2004); "Chechnya bomb: Security criticized", CNN World News, 13 Mayıs 2003, http://edition. cnn.com/2003/WORLD/europe/05/13/chechnya.blastindex.html, (Erişim Tarihi: 9 Eylül 2004).
}

305

Güvenlik

Stratejileri

Y11: 14

Say1: 28 

terör saldırılarıyla Çeçen sorunu arasında benzerlik kuran açıklamalarıyla Rusya'nın böyle bir firsatı değerlendireceğini göstermişti. ${ }^{66}$ Aslında bu tarz benzetmeler, Rus politikacıları için yeni değildi. Geçmişte, Rus politikacılar, PKK ile Çeçenler arasında büyük benzerlik olduğunu iddia ederek, Türkiye'nin Kuzey Kafkasya'da etkin bir politika izlemesini engellemeye çalışmışlardı. ${ }^{67}$ Zamanın içinde Afganistan, Irak ve Suriye gibi çatışma alanlarında Çeçen militanların El Kaide ve ISIS (DAEŞ) gibi radikal İslamcı örgütler bünyesinde ön saflarda savaştığ 1 haberleri, Çeçenistan mücadelesine büyük gölge düşürdü. Daha da kötüsü, 16 Nisan 2013'te Çeçen asıllı Amerikan vatandaşı iki kardeşin Chicago maratonunun bitiş çizgisine bomba bırakarak üç kişinin ölmesine ve yaklaşı 200 kişinin yaralanmasına neden olması ve bu teröristlerin El Kaide sempatizanı çıkması, Çeçenlere yönelik ön yargıları ve güvensizliği daha önce hiç olmadığı kadar arttırdı. ${ }^{68}$

Nisan 2009'da, Putin, 2'nci Çeçenistan Savaşı'nın başarıyla sona erdiğini açıkladı. Gerçekten de Kadyrov'un milisleri ve polisleri ülke geneline hâkim olmuş ve denetimi büyük ölçüde ele geçirmişti. Çeçen gerillalar, her ne kadar küçük gruplar halinde mevcudiyetlerini koruyor olsalar da ses getirecek büyük eylem yapma kapasitelerini

\footnotetext{
${ }^{66}$ Coppieters, age, s. 394; Herd, age, s. 112-117; John Russell, "Exploitation of the 'Islamic Factor' in the Russo-Chechen Conflict Before and After 11 September 2001" in (ed.) Rick Fawn, Realignments in Russian Foreign Policy, Frank Cass, London, 2002, ss. 96-106; Brian Glyn Williams, "From 'Secessionist Rebels' to 'Al-Qaeda Shock Brigades': Assessing Russia's Efforts to Extend the Post-September 11th War on Terror to Chechnya", Comparative Studies of South Asia, Africa and the Middle East, Cilt XXIV/1, 2004, ss. 197-207.

67 "Çeçen-PKK Pazarlığı", Hürriyet, 23 Temmuz 1995; Robert Olson, "The Kurdish Question and Chechnya: Turkish and Russian Foreign Policies since the Gulf War", Middle East Policy, Cilt IV/3, Mart 1996, ss. 110-118.

${ }^{68}$ Tamerlan ve Dzhokhar Tsarnaev kardeşlerin Çeçenistan direnişi ile hiçbir bağlantılarının olmaması, Amerika'da yaşadıkları uyum sorunları sonucu radikalleştikleri akademik çalışmalar dışında göz ardı edilmiştir. Thérese Postel, "The Young and the Normless: Al Qaida's ideological Recruitment of Western Extremists", Connections, Cilt XII/4, ss. 99110; Joseph Yi, "Atomised Terror and Democratic Citizenship", The Political Quarterly, Cilt XXIV/3, Temmuz-Eylül 2013, ss. 388-393.
} 
kaybetmişlerdi. $\mathrm{Bu}$ zamana kadar, bağımsızlık mücadelesine büyük destek veren halk ise ya yerinden edilmiş, ya da sindirilmişti. Yalnız, Rusya'nın özelde Çeçenistan, genelde ise Kuzey Kafkasya politikasında iki önemli sorunu bulunmaktaydı. Birincisi, Putin ve diğer liderlerin bütün çabasına rağmen Kadyrov benzeri başarılı iş birlikçi liderler diğer Kafkas otonom bölgelerinde bulunulamadi. Tam tersine, Çeçenistan'da bağımsızlık mücadelesinin beli kırılırken başta Dağıstan ve İnguşetya olmak üzere bölgede çatışma ve terörizm artmıştır. İşin ilginç tarafi, Putin ve diğer Rus liderleri, Dudayev ve Maskhadov hükümetlerinin hayal bile edemeyeceği imkân ve özgürlüğü Kadyrov ailesine tanımışlardır. Bugün Çeçenistan devlet içinde devlet konumundadır. Her ne kadar Ramzan Kadyrov, Putin'e sadakat ve mutlak itaat göstermekteyse de, Rusya'ya ne kadar sadık olduğu şüphelidir. Kendi rejimi hakkında olumsuz yayın yapan gazeteci Anna Politkovskaya'nın ve insan hakları savunucusu Natalia Estemirova'nın öldürülmesinde rolü olduğu iddiaları ise, Kadyrov'un Çeçenistan sınırları dışında da gerektiğinde devletten bağımsız iş çevirdiğini göstermektedir. Ayrıca, Rusya, ülke dışında faaliyet gösteren Çeçen teröristlerden şikâyetçi olurken, Kadyrov'un milislerini Kırım'ın ilhakında ve Ukrayna ile Suriye gibi çatışma alanlarında kullanmaktan çekinmemiştir. Putin ve Ramzan Kadyrov arasındaki ilişkiye dayanan mevcut durumun ne kadar devam edebileceği, yoğun tartışma ve spekülasyonlara konu olmaktadır. ${ }^{69}$

\section{Sonuç}

Görüldüğg̈ gibi, uluslararası terör bağı ve medya organlarının varlığı dışında, Şeyh Şamil isyanı ile günümüzdeki Çeçenistan sorunu arasında büyük benzerlikler bulunmaktadır. Sanıldığının aksine, ne Çeçenlerin, ne de Rusya'nın uyguladıkları askerî ağırlıklı yöntemler yenidir. Silah teknolojisindeki gelişmeler göz ardı edildiğinde, her iki tarafın da çözümsüz eski yöntemlere saplanıp kaldıkları görülmektedir.

\footnotetext{
${ }^{69}$ Stephen Blank, Younkyoo Kim, "The North Caucasus: Russia's Other War", Journal of Slavic Military Studies, Cilt XXIX/2, 2016, ss. 190-194, 197-200; Ratelle, Souleimanov, age, ss. 1304-1310; Russell, age, ss. 1083-1086.
} 
308

Güvenlik

Stratejileri

Y11: 14

Sayı: 28

$\mathrm{Bu}$ esas tespit çerçevesinde, Çeçenler ve Rusya hakkındaki bulgularımızı aşağıdaki gibi sıralayabiliriz:

İlk olarak, Çeçenlerin bağımsız bir devlet kurabilmek için uygulamaya çalıştıkları temel askerî strateji, Çeçenistan içinde ve dışında Rus askerî ve sivil hedeflerine karşı gerilla savaşı ve terörizm karışımı savaştır. Amaç, Ruslara tahammül edemeyecekleri kadar insan zayiatı, siyasi, ekonomik ve prestij kaybı verdirerek Çeçenistan'dan çekilmeye zorlamaktır. Rusya'nın buna karşı geliştirdiği temel karşı strateji ise salt güç kullanarak klasik savaş yöntemleriyle isyanı ne pahasina olursa olsun bastırmak ve bunu yaparken de sivil-asker ayrımına dikkat etmemek ve hatta özellikle sivillere karşı çeşitli cezalandırma yöntemleri uygulayarak Çeçenleri mücadeleden vazgeçmeye zorlamaktır. Tabiatı gereği, gerilla ve karşı-gerilla savaşı uzun ve alabildiğine şiddetli ve yıkıcıdır. Savaşın sonunda her kim kazanırsa kazansın elde edeceği kısıtlı zenginlikleri de tahrip olmuş, yanmış, yıkılmış ve nüfusunun büyük kısmını uzun mücadelede yitirmiş bir ülkedir. Binlerce Çeçen 1860'larda mülteci olarak farklı ülkelere sığınan ataları gibi ülkelerini terk etmek zorunda kaldı. Barış tekrar ülkeye hakim olsa bile, bunların çoğunluğu geçmiş yüzyılın mültecileri gibi geri dönemeyecektir.

İkinci olarak, Çeçenler farklı klan, aşiret ve grupları bir araya getirebilmek için şimdiye kadar İslamiyet dışında birleştirici bir ideoloji bulamadılar. Üstelik İslamiyet'i mücadeleyi Kafkaslara yaymak ve Müslüman ülkelerden destek almak için de önemli bir öğe olarak algılamaktadırlar. Mücadele uzayıp sertleştikçe İslamiyet öğesi daha ön plana çıtı ve radikalleşti. Şeyh Şamil Gürcistan'a akın düzenleyip Gürcü soyluların ailelerini kaçırarak Ruslarla iş birliği yapanları cezalandırmaya çalışmışı. Günümüz İslamcı Çeçen liderleri ise küresel radikal İslamcı terör örgütleriyle iş birliği kurarak güçlerini arttırmaya çalıştı. Sonuçta, her iki yöntem de başarısız oldu. Beklentinin tam tersine, radikal İslam Çeçenlerin kendi içlerindeki bölünmelerin artmadı ve dış dünyanın sempatisinin kaybedilmesine neden oldu. 20'nci yüzyıldaki başarılı gerilla hareketleri incelendiğinde, halkı harekete geçiren ve güçlüklere dayanmasını sağlayan ideolojinin milliyetçilik olduğu görülmektedir. Vietnam'da bile Komünizm kılıfı içinde aşırı 
milliyetçi söylemle kitleler seferber edilmiştir. Çeçenistan'da milliyetçiliğin başarısızlığ 1 sonucu, dine bir ideoloji olarak sarılmak, doğal olarak, savaşta başarıyı sağlamamıştır. Tam tersine, düşmana büyük bir koz verilmiştir. Rus yönetimi mücadelenin İslami özelliğine vurgu yaparak ve böylece Rus kamuoyunun endişe ve korkularından istifade ederek kamuoyu desteğini muhafaza etmeye ve aynı zamanda dünya kamuoyunun da desteğini kazanmaya çalışmıştır. Bazı Çeçen mültecilerin, Boston bombalama eyleminde olduğu gibi, sığındıkları ülkelerde muhtelif terör eylemlerine katılmaları Çeçen davasına büyük zarar vermiştir.

Üçüncü olarak, mücadelenin uzaması ve güç kullanma dışındaki seçeneklere kapalılık, her iki tarafın liderlik ve karar verme sürecini olumsuz yönde etkilemektedir. Çeçen cephesinde gerçekçi ve 1 lıml1 liderler ya güçlerini kaybettiler ya da öldürüldüler ve yerlerini hayalci radikaller aldı. Rusya'da ise Çeçenistan sorunu liderlik mücadelesinin bir aracı haline getirildi. Gerek Rus çarları, gerekse Yeltsin ve Putin, sorunu kendi güçlerini artırmak ve rakiplerini yok etmek için kullandılar. Bunun sonucunda, sorun bu liderlerin kendi kişisel sorunları haline dönüştü. Sorunun kişiselleşmesi ise çatışma yönetimi ve çözümünü olumsuz yönde etkiledi. Rus liderlerinin en önemli hatas1 Voronzov ile Bariatinsky'nin uyguladıkları ve başarı sağlayan halkı kazanma yöntemlerinden kaçınmalarıdır. Oysa, bu yöntemler bir paket halinde uygulandıkları kısa sürede bile bölgeye barışın dönmesini sağlamıştı. Bu yöntemler uygulamadan kaldırılmasıydı, muhtemelen bugünkü kriz ile karşı karşıya kalınmazdı. Şu an Kadyrov ailesine dayanılarak tesis edilen barış ise temelsiz ve oldukça kırılgandır.

Sonuç olarak, hâlihazırdaki dinamikler çerçevesinde, Çeçenistan sorununu her iki tarafın da kendi başlarına çözmeleri mümkün gözükmemektedir. Bölgede kalıcı bir çözüme ulaşılması için uluslararası toplumun inisiyatifi ele alması gerekmektedir. Aksi takdirde, şimdilik Kuzey Kafkasya'nın sınırlı bir bölgesini etkileyen sorunun daha geniş coğrafyalara yayılması kuvvetle muhtemeldir. Bölgenin ve dünyanın güvenlik ve istikrarı için her iki tarafta da büyük yıkıma sebebiyet veren çatışmanın bir an önce sona erdirilmesinde büyük fayda vardır. 
Güvenlik

Stratejileri

Y11: 14

Sayı: 28

\section{Summary}

The Caucasus region has a unique geography and ethnicity. The region has been an important crossing point for trade, migration, and of course military invasion between Asia and Europe for centuries. Sitting in-between two important civilizations (Christianity and Islam) and having an intense flow of people over its territory, the Caucasus region brought together many people of different ethnic and religious backgrounds. This unique geographic position of the Caucasus has made the region a target for Russians who have had the strategy of reaching to warm seas and descending to the south. The Russian invasion of the region started with the establishment of Petrovsk base in 1722 and the Russians gained the ability to carry out regular military expeditions into the deeper parts of the region. Thus, Chechens have fought against Russian occupation and administration since 1750 by themselves or with other Caucasian nations. This struggle has reached its peak once in 1850s and then again in 1990s. This study examines and compares these two peaks: rebellion of Sheik Shamil between 1832 and 1859 and Chechens' struggle for independence from 1991 to 2009 (the First and Second Chechen Wars). The main thesis of the author is that both Chechens and Russians had applied the same pointless strategies and methods and that they had not learned anything from history. The author aims to reveal the similarities and differences between these two peaks in the history and to shed a light on a possible solution for the current struggle in the region.

There are many similarities between the rebellion of Sheik Shamil in the mid-1800s and the Chechens' struggle for independence in the 1990s and 2000s. Contrary to popular beliefs, the militaryoriented methods both of the Chechens and of the Russians cannot be considered as new. Apart from the developments in the weapon technologies, both sides are stuck in their old methods which have not provided any solution. Within the framework of current dynamics of the region, it seems impossible for both sides to solve the problem in the region. The international community should take the initiative in order to achieve a permanent solution in the region. Otherwise, the problem, which has only affected a limited area of the northern 
Caucasus for the time being, is most likely to spread to a broader geography. It is of great benefit for both Chechens and Russians to end the conflict, which has caused great destruction on both sides, in order to achieve security and stability in the region and in the world.

\section{Kaynakça}

\section{Kitaplar}

BERKOK, İsmail, Tarihte Kafkasya, İstanbul Matbaas1, İstanbul, 1953. BLANCH, Lesley, The Sabres of Paradise, John Murray, 1960, London. BUTBAY, Mustafa, Kafkasya Hatıraları, çev. A.C. Canbulat, TTK Basımevi, Ankara, 1996.

GALL, Carlotta ve Thomas de Waal, Checnya: A Small Victorious War, Pan Boks, 1997, London.

GAMMER, Moshe, Muslim Resistance to the Tsar: Shamil and the Conquest of Chechnia and Dagestan, Frank Cass, 1994, London. GRIGORIANTZ, Alexander, Kafkasya Halklart: Tarihi ve Etnografik Bir Sentez, (çev.) D. Yurdakul, 1. bask1, Sabah Kitapları, 1999, İstanbul. HENZE, Paul B., Kafkaslarda Ateş ve Kılıç: 19ncu Yüzyılda Kuzey Kafkasya Dă̆ Köylülerinin Direnişi, (çev.) A. Kösetorunu, ODTÜ Mimarlık Fak. Yay., Ankara, 1985.

HUNTER, Virginia, Past and Process in Herodotus and Thucydides, Princeton University Press, Princeton, 1982.

KARÂHİ, M. Tahir el, Kafkasya Mücahidi Şeyh Şamil'in Hattralart, (haz.) H. Ahmet Özdemir, Kültür Bakanlığı Yayınları, Ankara, 2000.

KRUGER, Rayne, Good-bye Dolly Gray: The Story of the Boer War, 2. bask1, Pan Books, London, 1977.

LUCE, T.J., The Greek Historians, Routledge, 1997, London.

MILYOTIN [General Dimitri Milyutin], 1839 Senesinde Şimali Dağıstan'da Yapılan Harp Harekâtı, (çev.) A. Şevket, Askerî Matbaa, İstanbul, 1931. 
SMITH, Sebastian, Allah's Mountains: The Battle for Chechnya, Tauris Parke, London, 2006.

Güvenlik Stratejileri

Y11: 14

Sayı: 28 YÜCEER, Nasır, Birinci Dünya Savaşı'nda Osmanlı Ordusu'nun Azerbaycan ve Dağııstan Harekâtı, Gnkur. Basımevi, Ankara, 1996. Makaleler ve Kitap Bölümleri AKHMADOV, Ilyas, "The Russian-Chechen Tragedy: The Way to Peace and Democracy", Central Asian Survey, Cilt XXII/4, Aralık 2003.

Anonim, "What Life is Like in Chechnya under the Russian Occupationthe Realities of Today's Chechnya", Central Asian Survey, Cilt XXII/4, Aralık 2003.

ASHOUR, Omar, "Security, Oil and Internal Politics: The Causes of the Russo-Chechen Conflicts", Studies in Conflict\&Terrorism, Cilt XXVII, 2003.

BLANDY, Charles W., "Military Aspects of the Two Russo-Chechen Conflicts in Recent Times", Central Asian Survey, Cilt XXII/4, Aralık 2003.

BLANK, Stephen, "Russia's Real Drive to the South", ORBIS, Cilt XXIX/3, Yaz 1995.

BLANK, Stephen, "Yeltsin's Folly: The Russian Invasion of Chechnya", Mediterranean Quarterly, Cilt VI/3, Yaz 1995.

BLANK, Stephen, Younkyoo Kim, "The North Caucasus: Russia's Other War", Journal of Slavic Military Studies, Cilt XXIX/2, 2016.

COLARUSSO, John, "Chechnya: The War Without Winners", Current History, Cilt XCIV/594, Ekim 1995.

COPPIETERS, Bruno, "Secession and War: A Moral Analysis of the Russian-Chechen Conflict", Central Asian Survey, Cilt XXIII/4, Aralık 2003.

CORNELL, Svante E., "International Reactions to Massive Human Rights Violations: The Case of Chechnya", Europe-Asia Studies, Cilt LI/1, Ocak 1999.

DERLYGUIAN, Georgi M., "Che Guevaras in Turbans", New Left Review, no. 237, Eylül-Ekim 1999.

DUNLOP, John B., "How Many Soldiers and Civilians Died during the Russo-Chechen War of 1994-1996?", Central Asian Survey, Cilt XIX/3-4, 2000. 
GAMMER, Moshe, "A Switzer in the Caucasus: Faesy's Campaigns in Chechnia and Daghestan", Middle Eastern Studies, Cilt XXX/3, Temmuz 1994.

GÖKAY, Bülent, "Chechnia: A Long History of Conflict, Ressistance and Oppression", Alternatives, Cilt III/2-3, Yaz-Sonbahar 2004.

GÜNEY, Niyazi, "Kuzey Kafkasya ve Çeçenistan”, Yeni Türkiye, Cilt I/3, Mart-Nisan 1995.

GÜNE-YADCY, Zübeyde, “A Chechen National Hero of the Caucasus in the 18th Century: Sheikh Mansur", Central Asian Survey, Cilt XXII/1, Mart 2003.

HERD, Graeme P., "The Russo-Chechen Information Warfare and 9/11: Al-Qaeda throught the South Caucasus Looking Glass?", (ed.) Rick Fawn, Realignments in Russian Foreign Policy, Frank Cass, London, 2002.

KISRIEV, Enver, Robert Bruce Ware, "Conflict and Catharsis: A Report on Developments in Dagestan Following the Incursions of August and September 1999”, Nationalities Papers, Cilt XXVIII/3, 2000.

KÖK, Havva, "Chechen Crisis and Russia's Future", Foreign Policy, Cilt XIX/1-2, 1995.

LAMBETH, Benjamin S., "Russia's Wounded Military," Foreign Affairs, Cilt LXXIV/2, Mart-Nisan, 1995.

LIEVEN, Anatol, Chechnya: Tombstone of Russian Power, Yale University Press, New Haven, 1998.

MOSKALEV, Boris, "The Anatomy of the Chechen Conflict", Mediterranean Quarterly, Cilt VII/1, Kış 1996.

OLSON, Robert, "The Kurdish Question and Chechnya: Turkish and Russian Foreign Policies since the Gulf War", Middle East Policy, Cilt IV/3, Mart 1996.

PORCH, Douglas, "Bugeaud, Galliéni, Lyautey: The Development of French Colonial Warfare", (ed.) Peter Paret, John Shy, Makers of Modern Strategy: From Machiavelli to the Nuclear Age, 2. bask1, Princeton Uni. Press, Princeton, 1986.

POSTEL, Thérese, "The Young and the Normless: Al Qaida's ideological Recruitment of Western Extremists", Connections, Cilt XII/4. 
RATELLE, Jean-François, Emil Aslan Souleimanov, "A Perfect Counterinsurgency? Making Sense of Moscow's Policy of Chechenisation", Europe-Asia Studies, Cilt LXVIII/8, Ekim 2016.

Y11: 14 RUSSELL, John, "Chechen Elites: Control, Cooption or Substitution?”, Europe-Asia Studies, Cilt LXIII/6, Ağustos 2011. RUSSELL, John, "Exploitation of the 'Islamic Factor' in the RussoChechen Conflict Before and After 11 September 2001" in (ed.) Rick Fawn, Realignments in Russian Foreign Policy, Frank Cass, London, 2002. SAYDAM, Abdullah, "Freedom Movements in Northern Caucasia", Eurasian Studies, Cilt. II/1, İlkbahar 1995.

TAVKUL, Ufuk, "Sovyet Döneminde Kuzey Kafkasya'da Kentleşme", Tarih ve Toplum, Cilt XVI/94, Ekim 1991.

THOMAS, Timothy L., "The Battle of Grozny: Deadly Classroom for Urban Combat", Parameters, Cilt XXIX/2, Yaz 1999.

TURBIVILLE, Graham H., "The Chechen Ethno-Religious Conflict, Terrorism and Crime", Military Review, Cilt LXXIV/3, Mart 1994.

WILLIAMS, Brian Glyn, "From 'Secessionist Rebels' to 'Al-Qaeda Shock Brigades': Assessing Russia's Efforts to Extend the PostSeptember 11th War on Terror to Chechnya", Comparative Studies of South Asia, Africa and the Middle East, Cilt XXIV/1, 2004.

YI, Joseph, "Atomised Terror and Democratic Citizenship", The Political Quarterly, Cilt XXIV/3, Temmuz-Eylül 2013.

\section{Bildiriler}

ALPARGU, Mehmet, “İkinci Dünya Savaşı'nda Sovyetler'in Kafkasya'daki Tehcir (Sürgün) Uygulamaları", Alttncı Askeri Tarih Semineri Bildirileri, Cilt I, Gnkur Basımevi, Ankara, 1998.

\section{Haberler}

"Chechen Hostage Crisis", Keesing's Record of Word Events, Cilt XLIV/6, 24 Haziran 1995.

"Chechen Rebels Release Hostages After Raid on Russian Town", Facts on File, c. 55, no. 5847, 22 Haziran 1995.

"Chechnya bomb: Security criticized", CNN World News, 13 May1s 2003, http://edition.cnn.com/2003/WORLD/europe/05/13/chechnya. blast/index.html, (Erişim Tarihi: 9 Eylül 2004). 
"Chechnya Bombardment Renewed", Facts on File, Cilt LV/2828, 9 Şubat 1995.

"Chechnya Truce Reached, Broken", Facts on File, Cilt LV/2830, 23 Şubat 1995.

"Çeçen-PKK Pazarlığı", Hürriyet, 23 Temmuz 1995.

"Explosions "led to Russia crashes"”, CNN World News, 30 Ağustos 2004, http://edition.cnn.com/2004/ WORLD/europe/08/30/russia. planecrash/index.html, (Erişim Tarihi: 9 Eylül 2004).

"Gas killed 115 Moscow hostages", CNN World News, 27 Ekim 2002, http://edition.cnn.com/2002/WORLD/europe/10/27/moscow.deaths/ index.html, (Erişim Tarihi: 9 Eylül 2004).

"Moscow metro blast kills 39", CNN World News, 6 Şubat bomber kills 9", CNN World News, 1 Eylül 2004, http://edition.cnn.com/2004/ WORLD/ europe/08/31/russia.carblast/index.html, (Erişim Tarihi: 9 Eylül 2004).

"Russia Capture Chechen - Held Village: Many Hostages Freed After Massive Bombardment" Facts on File, Cilt LVI/2876, 18 Ocak, 1996. "Russia, Chechnya Reach Truce in Secession Conflict", Facts on File, Cilt LV/2853, 3 Ağustos 1995.

"Russian suicide blast: Dozens dead", CNN World News, 4 Ağustos 2003, http://edition.cnn.com/ 2003/WORLD/europe/08/01/russia.blast /index.html, (Erişim Tarihi: 9 Eylül 2004).

"Samashki Raid Targeted Civilians", Facts on File, Cilt LV/2841, 11 May1s 1995.

"Timeline: Russia terror attacks", CNN World News, 2 Eylül 2004, http://edition.cnn.com/2004/ WORLD /europe/09/01/russia.timeline/ index.html, (Erişim Tarihi: 9 Eylül 2004).

"Toll rises from Russia attack", CNN World News, 23 Haziran 2004 http://edition.cnn.com/2004/WORLD/ europe/06/23/russia.toll/index.html, (Erişim Tarihi: 9 Eylül 2004). BLOTSKY, Oleg "Lessons not Learned", Time, 20 Şubat 1995. CHURCH, George J., "Death Trap", Time, 16 Ocak 1995. JACKSON, James O., "Pale, Rested and Ready", Time, 22 Ocak 1996. KOHAN, John, "Halfway to Peace", Time, 14 Ağustos 1995.

MEIER, Andrew, Paul Quinn-Judge, "War Clouds Over Chechnya", Time, 17 Ocak 2000. 
NELAN, Bruce W., "Why it all Went so very Wrong", Time, 16 Ocak 1995.

QUINN-JUDGE, Paul, "Back into The Inferno", Time, 11 Ekim 1999.

Y11: 14 QUINN-JUDGE, Paul, "Chechen Hell”, Time, 6 Aralık 1999. 
FELYENHAUER, Pavel, "The Chechen Campaign", http://www.amina.com/article/politics.shtml, (Erişim Tarihi: 9 Mart 2000). FINCH, Raymond C., "Why the Russian Military Failed in Chechnya", Foreign Military Studies Office, http://call.army.mil/call/fmso/ fmsopubs/issues/yrusfail/yrusfail.htm, (Erişim Tarihi: 10 Temmuz 2000). KANFAS, Roger, "Remembering the 1944 Chechen Deportation", http://www.amina.com article/politics. shtml, (Erişim Tarihi: 9 Mart 2000). KRAMER, David. J., "Time to Act on Chechnya", http://www. amina.com/article/politics.shtml, (Erişim Tarihi: 9 Mart 2000).

LIEVEN, Anatol, "Freedom and Anarchy, Russia Stumbles Toward the Twenty-First Century", http://www.amina.com/ article/politics.shtml, (Erişim Tarihi: 9 Mart 2000).

MARGOLIS, Eric, "Crime without Punishment-Russia in the Caucasus", http://www.amina.com/ article/ politics.shtml, (Erişim Tarihi: 9 Mart 2000).

TORIN, Vladimir, "The Workings of the Caucasian Mechanism", http://www.amina.com, (Erişim Tarihi: 9 Mart 2000);

YEVTUSHENKO, Aleksandr, "Interview with Ruslan Khasbulatov", February 25, 1998, http://www.amina.com/ article/politics.shtml, (Erişim Tarihi: 9 Mart 2000). 